\title{
18. ISOTOPIC AND FAUNAL RECORD OF PALEOGENE DEEP-WATER TRANSITIONS IN THE NORTH PACIFIC ${ }^{1}$
}

\author{
Dorothy K. Pak ${ }^{2}$ and Kenneth G. Miller ${ }^{3}$
}

\begin{abstract}
The climatic change from early Eocene warmth to the onset of Oligocene continental glaciation may have been associated with changes in deep-water circulation. The North Pacific Transect (Ocean Drilling Program Leg 145) recovered Paleogene carbonates at Site 883 (2000 m paleodepth; upper Paleocene to lower Oligocene) and Site 884 (3300 m paleodepth; lower Eocene to lower Oligocene), providing a middle and upper Eocene isotope record from the North Pacific. These new data, combined with existing data from Site 577, allow the construction of a late Paleocene and Eocene composite Pacific isotopic record.

Interbasinal isotopic comparisons indicate that during the early middle to middle middle Eocene (ca. 51-46 Ma) the Southern Ocean was the sole source of deep water to the North Pacific. However, during the early Eocene (ca. 57-52 Ma) and the middle middle Eocene to Oligocene (ca. 46-36 Ma), there were two sources of deep water: a cool, nutrient-depleted source originating in the Southern Ocean and a warmer, more nutrient-enriched source probably originating in mid-latitudes.

Deep-water circulation changes have the potential to profoundly affect benthic foraminifer communities. During the early Eocene, the deep Site 884 was characterized by a distinct abyssal $(>3000 \mathrm{~m})$ agglutinated foraminiferal faunal assemblage. The abyssal assemblage disappeared near the early/middle Eocene boundary, coinciding with both the first Cenozoic deep-water cooling step and an inferred shift in circulation from a two-source to a one-source mode. We suggest that benthic foraminifer assemblages responded to both rapid cooling and decreased corrosivity as the circulation regime shifted from one mode to another.
\end{abstract}

\section{INTRODUCTION}

Early Eocene ( $\sim 52 \mathrm{Ma})$ climate was the warmest of the Cenozoic, with deep-water temperatures of $10^{\circ}-15^{\circ} \mathrm{C}$ (Shackleton and Boersma, 1983; Miller et al., 1987a; Zachos et al., 1994). By the earliest Oligocene, deep-water temperatures had cooled to $\sim 2^{\circ}-4^{\circ} \mathrm{C}$ and major ice sheets had begun to build on Antarctica (Wise et al., 1985; Shackleton, 1986; Barron et al., 1991). Although this trend was one of the most important climate transitions of the Cenozoic, significant gaps exist in our understanding of its nature and timing. In this study, we examine benthic foraminifer isotopic and faunal records from three Pacific Eocene deep- and intermediate-water sections. We provide the first North Pacific middle and upper Eocene isotope record. As the largest global reservoir of deep water (and of carbon), the Pacific record represents a critical aspect of circulation that has been unavailable until now. Using these records, we address three questions: (1) Was climatic cooling accompanied by shifts in deep- or intermediate-water circulation? (2) What was the vertical temperature structure of the Eocene deep North Pacific? and (3) Were changes in benthic foraminifer assemblages related to deep-water cooling and/or circulation changes?

\section{Eocene Deep-Water Formation}

Changes in deep-water circulation can alter climate through the interhemispheric transport of heat and salt, as well as by regulating the atmospheric $\mathrm{CO}_{2}$ content (e.g., Broecker and Denton, 1989). In the modern ocean, deep waters form in polar regions during sea-ice formation (as in Antarctic Bottom Water [AABW]) or as a result of intense cooling and evaporation of warm surface waters advected into polar oceans (as in North Atlantic Deep Water [NADW]). The evaporative heat released during NADW formation plays a vital role in the modulation of local climate and changes in the production rate of

\footnotetext{
${ }^{1}$ Rea, D.K., Basov, I.A., Scholl, D.W., and Allan, J.F. (Eds.), 1995. Proc. ODP, Sci. Results, 145: College Station, TX (Ocean Drilling Program)

${ }^{2}$ Lamont-Doherty Earth Observatory and Department of Geological Sciences, Columbia University, Palisades, NY 10994, U.S.A.

${ }^{3}$ Department of Geological Sciences, Rutgers University, New Brunswick, NJ 08855 , U.S.A.
}

NADW were strongly linked to late Pleistocene glacial-interglacial cycles (e.g., Broecker and Denton, 1989).

Isotopic data indicate that during most of the Eocene polar surface waters were warm $\left(>10^{\circ} \mathrm{C}\right)$, whereas equatorial temperatures may have remained relatively stable (Shackleton and Boersma, 1983; Zachos et al., 1994). The low thermal gradient and absence of polar sea ice has led to debate about the modes of formation of Eocene deep waters. Specifically, were the high latitudes cold enough to be a major source of bottom waters? Alternatively, the deep ocean may have been ventilated by warm saline deep water (WSDW) formed by high evaporation rates at mid-latitudes. Although several authors have argued that Eocene paleogeographic and climatic conditions favored the formation of a mid-latitude WSDW (Chamberlin, 1906; Brass et al., 1982; Barron, 1987; Barron and Peterson, 1991), little isotopic or faunal evidence exists to support this idea. Reconstructions of the vertical temperature gradient in the Eocene ocean have been hindered by the lack of appropriate depth transects. One exception has been a study of the vertical isotopic gradient across intermediate-water depths in the Southern Ocean (Kennett and Stott, 1990) showing that late Eocene $\delta^{18} \mathrm{O}$ values at the deeper site were lower than at the shallower site. This observation led the authors to suggest that the deeper site was influenced by WSDW during most of the Eocene. However, Kennett and Stott's (1990) deepest site had an Eocene paleodepth of approximately $2000 \mathrm{~m}$ and does not reflect conditions in the deep basin. Mead et al. (1993) subsequently studied the late Eocene to Oligocene vertical isotopic gradient in the subantarctic in order to determine whether a halothermal water mass, if present, was primarily restricted to intermediate or deep depths. They concluded that WSDW influenced the deep subantarctic from approximately 2000 to $3400 \mathrm{~m}$ and was overlain by a colder water mass at intermediate (1500-2000 m) depths. Additional vertical transects from deep $(>3000 \mathrm{~m})$ through intermediate water depths are necessary to test the presence and importance of WSDW during the Paleocene and Eocene.

Interbasinal comparisons of late Paleocene to early Eocene $\delta^{18} \mathrm{O}$ and $\delta^{13} \mathrm{C}$ values indicate that, although there were two early Eocene sources of deep water with different $\delta^{18} \mathrm{O}$ signatures, the Southern Ocean remained an important source throughout the late Paleocene to early Eocene (Pak and Miller, 1992). Similarly, Southern Ocean planktonic and benthic foraminifer $\delta^{18} \mathrm{O}$ values were similar through- 
out the Eocene (Barrera and Huber, 1991; Zachos et al., 1994), indicating that the Southern Ocean was a source of deep water at this time.

Neither the sources of Eocene deep water nor the vertical temperature structure of the Eocene ocean is well constrained. However, substantial isotopic evidence exists for Eocene deep-water cooling. Isotopic and faunal data indicate that early Eocene climates were the warmest of the Cenozoic. Deep waters at this time were as warm as $15^{\circ} \mathrm{C}$. Fossil remains of tropical faunas have been found as far north as Alaska (Wolfe, 1978), indicating high-latitude continental warmth. Subsequent to the early Eocene peak warmth, climate cooled throughout the remainder of the Eocene (Savin et al., 1975; Shackleton and Kennett, 1975; Savin, 1977; Miller et al., 1987a). The benthic foraminifer $\delta^{18} \mathrm{O}$ data available indicate that the Eocene deep-water cooling took place as a series of at least three steps (Miller, 1992): near the early/middle Eocene boundary, near the middle/late Eocene boundary, and in the earliest Oligocene. Although the earliest Oligocene shift is well established (Savin et al., 1975; Shackleton and Kennett, 1975; Miller et al., 1987a), the two middle Eocene steps are not well constrained in terms of either timing or magnitude (Miller, 1992). The early/middle Eocene $\delta^{18} \mathrm{O}$ increase is characterized as a rapid increase of $\sim 1.0 \%$ beginning in Chron C22n (Shackleton et al., 1984; Miller, 1992) and continuing through C21 (Katz and Miller, 1991; Miller, 1992 ), thus spanning the early/middle Eocene boundary. The middle/ late Eocene $\delta^{18} \mathrm{O}$ increase was also approximately $1.0 \%$ in magnitude (Shackleton and Kennett, 1975; Oberhänsli et al., 1984; Keigwin and Corliss, 1986). The timing of this step is poorly constrained; however, based on biostratigraphic relationships at subantarctic Site 702, the increase occurred in the latest middle Eocene (Katz and Miller, 1991). The timing of the early Oligocene shift is constrained to within $\mathrm{C} 13 \mathrm{n}$, subsequent to the last occurrence (LO) of Hantkenina spp., clearly placing the shift within the earliest Oligocene (Keigwin, 1980; Miller, 1992). The step was characterized by a benthic foraminifer $\delta^{18} \mathrm{O}$ increase of $\sim 1.0 \% 0-1.5 \%$. A coeval planktonic foraminiferal $\delta^{18} \mathrm{O}$ increase of $\sim 1 \%$ suggests that at least $0.3 \%-1.0 \%$ of the increase is attributable to ice growth, leaving approximately $0.5 \%-1.2 \%$ o $\left(2^{\circ}-\right.$ $6^{\circ} \mathrm{C}$ ) attributable to cooling (Miller et al., 1987a).

\section{Eocene Benthic Foraminifer Faunal Events}

Deep-water circulation and temperature changes may have had a profound effect on benthic foraminifer communities. The most important benthic foraminifer turnover of the Cenozoic occurred in the latest Paleocene, when approximately $50 \%$ of the benthic fauna became extinct within a few thousand years (Kennett and Stott, 1991). This event was identical in magnitude and timing in the Southern, Pacific, and Atlantic oceans, and was linked to probable deep-water warming and circulation change (e.g., Tjalsma and Lohmann, 1983; Thomas, 1990; Katz and Miller, 1991; Kennett and Stott, 1991; Pak and Miller, 1992).

A second benthic foraminifer turnover took place during the late middle Eocene to earliest Oligocene (P14-P18) (Tjalsma and Lohmann, 1983; Corliss and Keigwin, 1986; Miller et al., 1992; Thomas, 1992). Unlike the Paleocene/Eocene extinction event, the middle Eocene turnover was characterized by a more gradual increase in first and last occurrences. In addition, there were important late middle Eocene faunal abundance changes. The relative abundance of the cosmopolitan deep-water species Nuttallides truempyi decreased dramatically until its last occurrence near the end of the Eocene. In the late middle Eocene, Atlantic (Miller, 1983; Tjalsma and Lohmann, 1983; MüllerMerz and Oberhänsli, 1991), Caribbean (Tjalsma and Lohmann, 1983), and subantarctic (Miller et al., 1992) assemblages dominated by Nuttallides truempyi were replaced by those dominated by Cibicidoides praemundulus, Oridorsalis spp., Gyroidinoides, and Globocassidulina subglobosa. In the Southern Ocean, there was a middle Eocene decline in the abundance of heavily calcified buliminids (Thomas, 1992). The decrease in the relative abundance of $N$. truempyi was related to progressive deep-water cooling throughout the middle and late Eocene (Corliss and Keigwin, 1986; Miller et al., 1992; Thomas, 1992).
Paleogene benthic foraminifer faunal events were also characterized by bathymetric migrations. In a study of Paleogene benthic foraminifer faunas of the Atlantic and Caribbean, Tjalsma and Lohmann (1983) noted that faunal assemblages had wide bathymetric tolerances before the late Paleocene extinction. Subsequent to this extinction, two bathymetrically distinct biofacies developed. In the Atlantic and Caribbean, the Nuttallides-dominated assemblage gradually became restricted to abyssal depths $(>3000 \mathrm{~m})$, whereas the $C$. praemundulusdominated assemblage colonized the bathyal region $(<3000 \mathrm{~m})$. These biofacies maintained their approximate depth distributions until the end of the middle Eocene. However, in the Pacific and Southern oceans Nuttallides truempyi remained a common element of bathyal and lower bathyal assemblages (Thomas, 1990; Pak and Miller, 1992).

Although Paleogene faunal events are relatively well studied in the Atlantic and Southern oceans, few Pacific Paleogene sites yield high-quality benthic foraminifer records. This study provides information regarding the timing and extent of the middle Eocene turnover in the North Pacific and Eocene bathyal and abyssal depth migrations.

\section{METHODS}

The North Pacific Transect Leg 145 recovered Paleogene carbonates at two sites on the flank of Detroit Seamount (Fig. 1): Site 883 $\left(51^{\circ} 11.908^{\prime} \mathrm{N}, 167^{\circ} 46.128^{\prime} \mathrm{E}, 2384 \mathrm{~m}\right.$ present depth) and Site 884 $\left(51^{\circ} 27.026^{\prime} \mathrm{N}, 168^{\circ} 20.228^{\prime} \mathrm{E}, 3825 \mathrm{~m}\right.$ present depth). Samples were obtained from Sites 883 and 884 at approximately 150 -cm intervals (1 sample per section), corresponding to a sampling interval of about $100-300$ k.y. Each sample was disaggregated in a sodium metaphosphate and tapwater solution, washed through a $63-\mu \mathrm{m}$ sieve, and oven dried. Benthic foraminifers were picked from the $>150-\mu \mathrm{m}$ fraction and mounted on reference slides. One sample per section from Site 883 and all samples from Site 884 were picked for benthic foraminifer faunal analysis. In general, between 100 and 300 specimens were picked per sample. Samples with fewer than 100 individuals were omitted from the quantitative analysis.

We conducted Q-mode principal component and varimax factor analyses on the relative abundance (percentage) data, in order to examine faunal trends in depth and time. Principal components analysis uses a cosine theta matrix to determine eigenvalues and eigenvectors, normalizing the data to unit length. As a result, Q-mode analysis emphasizes the most abundant taxa.

Our identifications follow the taxonomy of Tjalsma and Lohmann (1983) and van Morkhoven et al. (1986). We follow Berggren and Miller (1989) in recognizing the following benthic foraminifer depth zones: upper bathyal $(200-600 \mathrm{~m})$, middle bathyal $(600-1000 \mathrm{~m})$, lower bathyal (1000-2000 m), upper abyssal (2000-3000 m), and lower abyssal (>3000 m). Paleodepths for the Detroit Seamount sites were estimated assuming simple thermal subsidence and empirical age-depth curves ("backtracking"; e.g., Berger and Winterer, 1974; Detrich et al., 1977; Sclater et al., 1977). The paleodepths of Sites 883 and 884 were calculated using a basement age of $70 \mathrm{Ma}$ and a subsidence parameter (k) of 300 . Eocene sediments at Site 883 were deposited in water depths of approximately $1700-2000 \mathrm{~m}$, whereas similarly aged sediments at Site 884 were deposited in water depths of $3000-3300 \mathrm{~m}$.

Isotopic analyses were performed on the taxa Nuttallides truempyi, Cibicidoides praemundulus, and Cibicidoides eocaenus. Samples were ultrasonically cleaned for $2-4 \mathrm{~s}$ and roasted at $370^{\circ} \mathrm{C}$ under vacuum for $1 \mathrm{hr}$. Isotopic measurements were conducted at LamontDoherty Earth Observatory using a Carousel- 48 automatic carbonate preparation device attached to a Finnigan MAT 251 mass spectrometer. Analytical error $(1 \sigma)$, based on 30 analyses on the carbonate standard NBS20, was $0.07 \%$ and $0.04 \%$ for $\delta^{18} \mathrm{O}$ and $\delta^{13} \mathrm{C}$, respectively. The data are reported referenced to PDB (Table 1).

We apply no species corrections to our Cibicidoides data. However, our compilation of 125 paired analyses of Paleocene and Eocene Nuttalides truempyi and Cibicidoides spp. shows that Nuttallides is 


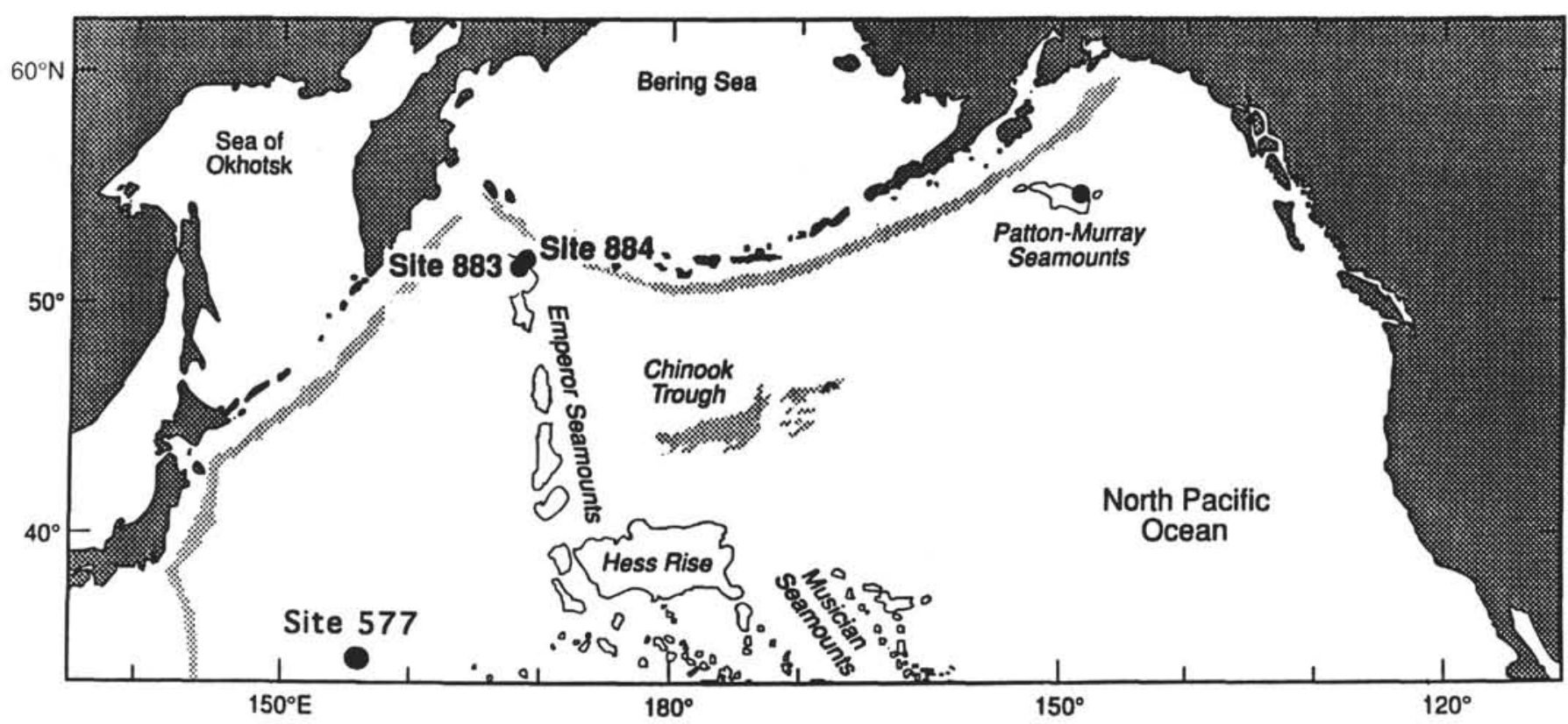

Figure 1. Map showing locations of sites used in this study.

lower than Cibicidoides by $0.1 \%$ in $\delta^{18} \mathrm{O}$ and $\sim 0.3 \%$ in $\delta^{13} \mathrm{C}$ (Fig. 2). These results are consistent with the results of similar compilations by Katz and Miller (1991) and Pak and Miller (1992). Therefore, so that we could compare Nuttallides data with Cibicidoides data, we have adjusted the Nuttallides data by the above correction factors.

One sample per section $(\sim 150 \mathrm{~cm})$ was analyzed for percentage of carbonate. Carbonate analyses were conducted on 0.5 -g subsamples using the vacuum-gasometric method of Jones and Kaiteris (1983). This method yields a precision of $<1 \%$.

\section{STRATIGRAPHY}

Stratigraphic control was provided by the revised shipboard nannofossil biostratigraphy (Rea, Basov, Janecek, Palmer-Julson et al., 1993). Additional datum levels were provided by planktonic (this study) and benthic (this study, using the datum levels of Berggren and Miller, 1989) foraminiferal biostratigraphies, as well as oxygen isotopic stratigraphy (this study). We employ the time scale of Berggren et al. (1985) to provide ages of the zonal boundaries, with the Paleocene/Eocene boundary of Aubry et al. (1988). The ages of our samples were estimated by linear interpolation between datum levels (Table 2). Cande and Kent (1992) have made major revisions (>2 m.y., in some cases) to much of the Paleogene geomagnetic polarity time scale. However, changes in the numeric ages of biostratigraphic datum levels do not affect the relative timing of events discussed here.

Site 883 recovered upper Paleocene (nannofossil Zone NP7/8 undifferentiated) to upper Oligocene (nannofossil Zone NP25) carbonates (Fig. 3). Within this sequence, at least three hiatuses or condensed zones are identified. The well-known latest Paleocene benthic foraminifer extinction event (e.g., Tjalsma and Lohmann, 1983; Thomas, 1990; Katz and Miller, 1991; Pak and Miller, 1992) occurred at approximately $813.22 \mathrm{~m}$ (between Samples 145-883B-85X-3, 105-110 cm, and 145-883-85-4, 10-15 cm), providing an upper Paleocene datum level. However, the uppermost Paleocene and lowermost Eocene section is highly condensed or missing, where approximately $3 \mathrm{~m} . \mathrm{y}$. of section is compressed into approximately $1 \mathrm{~m}$ (L. Beaufort, pers. comm., 1993). A second short (<1 m.y.) hiatus separates the lower Eocene (Samples 145-883B-85X-3, 129-134 cm, to 145-883B-82X-4, 95-100 cm; 813.19-784.65 mbsf) from a thick middle Eocene (Samples $145-883 \mathrm{~B}-82 \mathrm{X}-4,49-54 \mathrm{~cm}$, to $145-883 \mathrm{~B}-75 \mathrm{X}-1,30-35 \mathrm{~cm}$;
784.20-712.90 mbsf). A long hiatus ( $\sim 5$ m.y.) separates the middle Eocene section from the lower Oligocene.

The stratigraphy at Site 884 is uncertain for much of the section where spotty carbonate precluded shipboard biostratigraphies based on calcareous microfossils. The situation is also complicated by zones of slumping and core disturbance. However, using a combination of nannofossil, planktonic, and benthic foraminifer biostratigraphies, we identify a thick lower Eocene section (Fig. 4, Cores 145-884B$87 \mathrm{X}$ through $-83 \mathrm{X}$ ). The middle Eocene appears to be condensed at Site 884 , comprising only Cores $145-884 \mathrm{~B}-81 \mathrm{X}$ and $-82 \mathrm{X}$. The middle/upper Eocene boundary is tentatively placed in the lower part of Core 145-884B-80X (747.3 mbsf; between Samples 145-884B-81X$1,138-145 \mathrm{~cm}$, and $145-884 \mathrm{~B}-80 \mathrm{X}-5,75-80 \mathrm{~cm}$ ) based on the last occurrence (LO) of the benthic foraminifer taxon Aragonia aragonensis. It appears that a thick upper Eocene section is present at Site 884 , extending from the base of Core $145-884 \mathrm{~B}-80 \mathrm{X}$ to the middle of Core 145-884B-75X. We suspect that the Eocene/Oligocene boundary is unconformable, based on the sedimentological evidence (color change, slumping and reworking of benthic foraminifers). However, the biostratigraphic evidence indicates that the hiatus, if any, is short (all nannofossil zones are represented).

\section{RESULTS}

\section{Faunal Changes at Site 883}

Site 883 had an Eocene paleodepth of approximately $1800 \mathrm{~m}$ (lower bathyal). Benthic foraminifer assemblages are similar to depthcalibrated lower bathyal benthic assemblages in the Atlantic (e.g., Tjalsma and Lohmann, 1983). Thus, faunal results are consistent with the interpretation that deposition took place within the lower bathyal zone throughout the Paleogene. Examination of the benthic foraminifer ranges and the Q-mode factor results indicates that the upper Paleocene to lower Oligocene section at Site 883 is characterized by three faunal assemblages.

The upper Paleocene section, represented by a single sample (Sample $145-883 \mathrm{~B}-85 \mathrm{X}-4,10-15 \mathrm{~cm} ; 813.50 \mathrm{mbsf}$ ), was too thin to produce meaningful results in the quantitative analysis. However, the stratigraphic ranges reflect the late Paleocene turnover event (Fig. 5). Of the 33 taxa present in our upper Paleocene sample, 12 occur only within this sample, including Coryphostoma midwayensis, Neoeponides 
Table 1. $\delta^{18} \mathrm{O}$ and $\delta^{13} \mathrm{C}$ data from Sites 883 and 884 .

\begin{tabular}{|c|c|c|c|c|c|c|c|c|c|}
\hline $\begin{array}{l}\text { Core, section, } \\
\text { interval }(\mathrm{cm})\end{array}$ & $\begin{array}{l}\text { Depth } \\
\text { (mbsf) }\end{array}$ & $\begin{array}{l}\text { Age } \\
\text { (Ma) }\end{array}$ & $\delta^{18} \mathrm{O}$ & $\delta^{13} \mathrm{C}$ & $\begin{array}{l}\text { Core, section, } \\
\text { interval }(\mathrm{cm})\end{array}$ & $\begin{array}{l}\text { Depth } \\
\text { (mbsf) }\end{array}$ & $\begin{array}{l}\text { Age } \\
\text { (Ma) }\end{array}$ & $\delta^{18} \mathrm{O}$ & $\delta^{13} \mathrm{C}$ \\
\hline Site 884 Cibicidoides spp.: & & & & & $74 X-1,102-107$ & 704.20 & 36.33 & 1.84 & 1.35 \\
\hline 145-884B- & & & & & $74 \mathrm{X}-2,95-100$ & 705.45 & 36.43 & 1.84 & 1.29 \\
\hline $\begin{array}{l}73 X-2,103-108 \\
73 X-3,129-134\end{array}$ & $\begin{array}{l}673.53 \\
675.29\end{array}$ & $\begin{array}{l}34.57 \\
34.65\end{array}$ & $\begin{array}{l}1.48 \\
1.72\end{array}$ & $\begin{array}{l}0.50 \\
0.60\end{array}$ & Site 883 Nuttallides truempyi: & & & & \\
\hline & 676.25 & 34.69 & 1.53 & 0.40 & $145-883 B$ - & & & & \\
\hline $73 X-5,33-38$ & 677.33 & 34.74 & 1.66 & 0.40 & $75 X-1,30-35$ & 712.80 & 42.30 & 0.23 & 0.25 \\
\hline $74 X-1,0-5$ & 680.60 & 34.89 & 1.56 & 0.90 & $75 X-1,30-35$ & 712.80 & 42.30 & 0.18 & 0.18 \\
\hline $74 \times-7,10-15$ & 689.70 & 36.65 & 1.72 & 0.70 & $75 X-1,95-100$ & 713.55 & 42.43 & 0.15 & 0.19 \\
\hline $75 \times-3,128-133$ & 694.48 & 37.60 & 0.91 & 0.80 & $75 X-2,13-18$ & 713.96 & 42.51 & -0.13 & -0.10 \\
\hline $75 X-4,75-80$ & 695.45 & 37.72 & 0.31 & 0.50 & $75 X-4,95-100$ & 716.34 & 42.93 & 0.13 & 0.05 \\
\hline $80 \mathrm{X}-1,53-58$ & 738.93 & 39.63 & 0.66 & 0.40 & $75 X-5,94-99$ & 717.83 & 43.20 & 0.12 & -0.14 \\
\hline $80 X-4,119-124$ & 744.09 & 39.86 & 0.29 & 0.50 & $76 \mathrm{X}-1,54-59$ & 720.64 & 43.70 & 0.14 & 0.06 \\
\hline Site 884 Nuttallides truempyi: & & & & & $76 \mathrm{X}-1,95-100$ & 721.05 & 43.77 & 0.14 & 0.04 \\
\hline $145-884 \mathrm{~B}-$ & & & & & $76 \times-2,19-24$ & 721.79 & 43.90 & 0.12 & 0.22 \\
\hline $75 \times-4,75-80$ & 695.45 & 37.72 & 0.26 & 0.32 & $76 X-2,95-100$ & 722.55 & 44.03 & -0.05 & -0.03 \\
\hline $75 \times-5,140-145$ & 697.60 & 37.81 & 0.40 & 0.31 & $76 X-3,95-100$ & 724.05 & 44.30 & 0.08 & 0.01 \\
\hline $75 X-6,84-89$ & 698.54 & 37.86 & 0.10 & -0.03 & $76 \mathrm{X}-4,95-100$ & 725.55 & 44.57 & -0.11 & -0.30 \\
\hline $75 \times-7,12-17$ & 698.82 & 37.87 & 0.27 & 0.26 & $\begin{array}{l}76 X-5,95-100 \\
77 X-1,33-38\end{array}$ & $\begin{array}{l}727.05 \\
730.23\end{array}$ & $\begin{array}{l}44.84 \\
45.40\end{array}$ & 0.14 & $\begin{array}{r}0.01 \\
-0.05\end{array}$ \\
\hline $77 \times-3,73-78$ & 713.23 & 38.50 & 0.68 & 0.38 & $77 X-1,33-38$ & 730.23 & 45.40 & 0.16 & -0.05 \\
\hline $77 X-5,2-7$ & 715.52 & 38.60 & 0.43 & 0.37 & $77 \mathrm{X}-1,95-100$ & 730.85 & 45.51 & 0.02 & -0.17 \\
\hline $79 X-3,114-119$ & 732.94 & 39.37 & 0.60 & 0.26 & $77 X-2,33-38$ & 731.73 & 45.67 & 0.15 & 0.13 \\
\hline $79 X-5,113-118$ & 735.93 & 39.50 & 0.19 & 0.56 & $77 X-2,95-100$ & 732.35 & 45.78 & 0.11 & -0.07 \\
\hline $80 \times-4,119-124$ & 744.09 & 39.86 & 0.13 & 0.19 & $77 X-3,95-100$ & 733.85 & 46.05 & 0.12 & -0.13 \\
\hline $80 X-5,75-80$ & 745.15 & 39.90 & 0.39 & 0.70 & $77 X-3,135-140$ & 734.23 & 46.12 & 0.13 & 0.07 \\
\hline $81 X-1,138-145$ & 749.48 & 40.76 & 0.24 & 0.18 & $77 X-4,95-100$ & 735.35 & 46.31 & -0.14 & -0.16 \\
\hline $81 X-2,138-145$ & 750.98 & 41.34 & 0.02 & -0.16 & $77 X-5,38-43$ & 736.28 & 46.48 & -0.02 & 0.02 \\
\hline $81 X-3,110-115$ & 752.20 & 41.82 & 0.27 & 0.40 & $77 \times-5,55-60$ & 736.45 & 46.51 & 0.18 & 0.06 \\
\hline $81 X-4,50-55$ & 753.10 & 42.17 & 0.32 & 0.49 & $78 \times-1,52-57$ & 740.22 & 47.18 & -0.03 & -0.08 \\
\hline $82 X-1,52-57$ & 758.22 & 44.18 & 0.00 & -0.21 & $78 X-1,52-57$ & 740.22 & 47.18 & 0.09 & -0.02 \\
\hline $82 X-3,107-112$ & 761.77 & 45.57 & 0.13 & -0.17 & $78 X-1,122-127$ & 740.92 & 47.30 & 0.17 & 0.00 \\
\hline $82 X-3,107-112$ & 761.77 & 45.57 & 0.19 & -0.10 & $78 \times-2,100-105$ & 742.20 & 47.53 & -0.20 & -0.16 \\
\hline $82 X-4,79-84$ & 762.99 & 46.63 & 0.07 & 0.07 & $78 X-3,50-55$ & 743.20 & 47.71 & 0.16 & -0.15 \\
\hline $82 X-6,134-139$ & 766.54 & 50.91 & -0.38 & 0.42 & $78 X-3,95-100$ & 743.65 & 47.79 & -0.08 & -0.23 \\
\hline $83 X-1,72-77$ & 768.12 & 51.06 & -0.12 & 0.08 & $78 X-3,140-145$ & 744.10 & 47.87 & 0.15 & -0.12 \\
\hline $83 X-2,26-31$ & 769.16 & 51.15 & -0.05 & -0.08 & $78 \times-4,51-56$ & 744.71 & 47.98 & 0.00 & -0.18 \\
\hline $83 \times-3,10-15$ & 770.50 & 51.27 & 0.04 & -0.10 & $78 \times-4,51-56$ & 744.71 & 47.98 & 0.03 & -0.17 \\
\hline $83 \times-4,51-56$ & 772.41 & 51.45 & 0.31 & 0.08 & $78 \times-4,94-99$ & 745.14 & 48.05 & -0.01 & -0.21 \\
\hline $83 X-6,51-56$ & 775.41 & 51.72 & 0.38 & 0.03 & $78 \times-4,127-132$ & 745.47 & 48.11 & 0.03 & -0.17 \\
\hline $83 \times-7,65-70$ & 776.40 & 51.81 & 0.36 & 0.01 & $78 X-5,91-96$ & 746.61 & 48.32 & -0.10 & -0.32 \\
\hline $84 X-1,95-100$ & 777.95 & 51.95 & 0.47 & -0.10 & $78 \times-6,25-30$ & 747.45 & 48.47 & 0.13 & -0.25 \\
\hline $84 X-2,52-57$ & 779.02 & 52.05 & 0.14 & 0.05 & $78 X-6,95-100$ & 748.15 & 48.59 & 0.04 & -0.12 \\
\hline $84 X-5,100-105$ & 784.00 & 52.50 & -0.33 & 0.13 & $79 \times-1,94-99$ & 750.44 & 49.00 & -0.09 & -0.07 \\
\hline Site 883 Cibicidoides spp.: & & & & & $79 \times-1,122-127$ & 750.72 & 49.05 & -0.31 & 0.12 \\
\hline 145-883B- & & & & & $79 X-2,50-55$ & 751.50 & 49.19 & 0.05 & -0.14 \\
\hline $69 X-4,95-100$ & 660.25 & 24.43 & 1.68 & 0.28 & $79 \times-2,92-97$ & 751.92 & 49.26 & -0.49 & 0.16 \\
\hline $69 X-5,95-100$ & 661.75 & 25.86 & 1.38 & 0.04 & $79 X-2,109-114$ & 752.09 & 49.29 & -0.13 & -0.26 \\
\hline $69 \times-6,95-100$ & 663.23 & 27.90 & 2.15 & 0.63 & $79 \times-3,95-100$ & 753.45 & 49.53 & 0.03 & -0.04 \\
\hline $70 X-3,92-97$ & 668.35 & 32.37 & 1.85 & 0.06 & $79 X-3,140-145$ & 753.90 & 49.61 & 0.05 & 0.08 \\
\hline $70 \times-5,95-100$ & 671.35 & 33.90 & 2.04 & -0.03 & $80 \mathrm{X}-\mathrm{CC}$ & 769.20 & 50.15 & -0.57 & 0.05 \\
\hline $71 \times-4,100-105$ & 679.60 & 34.51 & 1.73 & 0.13 & $81 \mathrm{X}-\mathrm{CC}$ & 779.20 & 51.35 & -0.21 & 0.35 \\
\hline $71 X-5,95-100$ & 681.10 & 34.62 & 1.25 & -0.06 & $82 X-1,30-35$ & 779.50 & 51.41 & -0.60 & 0.68 \\
\hline $71 X-6,100-105$ & 682.60 & 34.73 & 1.92 & 0.08 & $82 X-1,95-100$ & 780.15 & 51.53 & -0.96 & 0.38 \\
\hline $72 \times-1,95-100$ & 684.65 & 34.89 & 1.64 & 0.54 & $82 X-1,122-127$ & 780.42 & 51.58 & -0.77 & 0.50 \\
\hline $72 X-2,95-100$ & 686.15 & 35.00 & 1.82 & 0.92 & $82 X-2,50-55$ & 781.20 & 51.73 & -0.60 & 0.58 \\
\hline $72 X-3,95-100$ & 687.65 & 35.11 & 1.62 & 0.77 & $82 X-2,95-100$ & 781.65 & 51.82 & -0.69 & 0.51 \\
\hline $72 X-4,95-100$ & 689.15 & 35.22 & 1.34 & 0.68 & $82 X-3,95-100$ & 783.15 & 52.10 & -0.74 & 0.52 \\
\hline $72 X-5,95-100$ & 690.65 & 35.33 & 1.39 & 0.80 & $82 X-4,95-100$ & 784.65 & 54.02 & -0.99 & -0.16 \\
\hline $73 \times-1,95-100$ & 694.25 & 35.60 & 1.51 & 0.82 & $82 X-5,95-100$ & 786.15 & 54.07 & -0.92 & 0.26 \\
\hline $73 \times-2,95-100$ & 695.75 & 35.71 & 1.58 & 0.79 & $82 X-6,95-100$ & 787.65 & 54.12 & -0.90 & 0.40 \\
\hline $73 X-3,50-55$ & 696.80 & 35.79 & 1.76 & 0.88 & $83 X-3,92-97$ & 793.12 & 54.32 & -0.95 & 0.47 \\
\hline $73 X-3,95-100$ & 697.25 & 35.82 & 1.68 & 0.77 & $84 X-1,45-50$ & 799.65 & 54.56 & -0.99 & 0.09 \\
\hline $73 \times-4,95-100$ & 698.75 & 35.93 & 1.56 & 0.63 & $84 X-1,65-69$ & 799.85 & 54.56 & -1.09 & -0.18 \\
\hline $73 X-4,140-145$ & 699.20 & 35.96 & 1.69 & 0.89 & $85 X-2,105-110$ & 811.45 & 54.98 & -0.91 & -0.29 \\
\hline $73 X-5,95-100$ & 700.25 & 36.04 & 1.55 & 0.82 & $85 \mathrm{X}-3,105-110$ & 812.95 & 57.09 & -0.78 & -0.23 \\
\hline $73 \times-6,95-100$ & 701.75 & 36.15 & 1.62 & 0.91 & $85 X-4,10-15$ & 813.50 & 58.17 & 0.10 & 1.43 \\
\hline $74 X-1,95-100$ & 703.95 & 36.31 & 1.98 & 0.95 & & & & & \\
\hline
\end{tabular}

lunata, Neoeponides hillebrandti, Pullenia coryelli, Spiroplectammina subhaeringensis, Stensioina beccariiformis, Tappanina selmensis, Tritaxia havanensis, Tritaxia trilatera, Bolivinoides delicatulus, and Bulimina midwayensis. Most of these species are characteristic of latest Paleocene benthic foraminifer assemblages described from other sequences (e.g., Tjalsma and Lohmann, 1983; Miller et al., 1987b; Thomas, 1990; Pak and Miller, 1992). The thin, possibly incomplete, nature of this section precludes determination of the timing of the turnover.

A lower to middle middle Eocene biofacies is recognized in Qmode Factor 1 (explaining $36 \%$ of the total variance) between Samples 145-883B-85X-3, 129-134 cm (813.19 mbsf), and -78X-1, 52$57 \mathrm{~cm}$ (740.22 mbsf; Fig. 6). Factor 1 closely reflects the percentage of Nuttallides truempyi (factor score 95.0), which was generally high in the early and early middle Eocene. Bulimina semicostata/jarvisi contributes high negative loadings on Factor 1 (-14.6), reflecting response to changes in $N$. truempyi abundance in the early and early middle Eocene. Both of these species diminished in importance in the middle middle Eocene.

Factor 2 (explaining $15 \%$ of the total variance) reflects a middle middle Eocene to Oligocene biofacies (Fig. 7). Taxa that contribute high loadings on Factor 2 include Oridorsalis (60.8), Gyroidinoides (48.2), and Cibicidoides praemundulus (39.8). Percentages of these taxa increased from the middle middle through late middle Eocene as part of a well-known lower bathyal and abyssal faunal abundance change (e.g., Miller, 1983; Tjalsma and Lohmann, 1983; MüllerMerz and Oberhänsli, 1991; Miller et al., 1992). The early Eocene Nuttallides truempyi assemblage was replaced in the late middle Eocene by an Oridorsalis/Gyroidinoides, C. praemundulus/Globo- 
cassidulina subglobosa biofacies (e.g., Tjalsma and Lohmann, 1983; Miller et al., 1992). Our data indicate that the timing of this change was similar in the Atlantic (e.g., Tjalsma and Lohmann, 1983, fig. 50) and Pacific oceans. At Site 883, G. subglobosa does not load heavily on Factor 2 (-6.8) but, instead, experiences an abundance peak in the middle middle Eocene ( 745-735 mbsf) where it temporarily dominates the fauna (Fig. 7).

In the Southern Ocean the middle to late Eocene transition is marked by the last appearance of the heavily calcified buliminids in the lower bathyal region (Thomas, 1990). At Site 883 several heavily calcified species of Bulimina (including Bulimina macilenta, B. callahani, and $B$. velascoensis) last occur in the late middle Eocene (between Samples 145-883B-75X-4, 95-100 cm, and -74X-2, 95-100 $\mathrm{cm}$; 716.34-705.45 mbsf). A single specimen of Bulimina semicostatal jarvisi within the Oligocene section (Sample 145-883B-73X-4, 95$100 \mathrm{~cm} ; 698.75 \mathrm{mbsf}$ ) may be the result of mixing.

The stratigraphic ranges of Site 883 species show an apparent increase in LOs within Core 145-883B-75X (Fig. 5). However, because approximately $5 \mathrm{~m}$.y. is missing between the middle Eocene and the lower Oligocene in this core, Site 883 does not show evidence of an Eocene/Oligocene mass extinction event but may reflect an extended interval of FOs and LOs as reported elsewhere (e.g., Miller et al., 1992).

\section{Faunal Changes at Site 884}

Site 884 lies approximately $1300 \mathrm{~m}$ deeper than Site 883 , having an abyssal Eocene paleodepth of $\sim 3100 \mathrm{~m}$. Comparisons of early Eocene assemblages from this deep Pacific site with those at Atlantic sites (Tjalsma and Lohmann, 1983; Miller, 1982/3) are consistent with its abyssal paleodepth, including high abundances of Nuttallides truempyi, Abyssamina spp. and Buliminella $\mathrm{cf}$. grata. However, the lower abyssal Pacific assemblages differ from those in the Atlantic by the lower abundances of Alabamina dissonata and Clinapertina spp. and by the high relative abundances of agglutinated taxa. Examination of the Q-mode factor results reveals two distinct biofacies within the lower Eocene to Oligocene section, represented by Factors 4 (explaining $5 \%$ of the total variance) and 2 (explaining $21 \%$ of the total variance; Figs. 8,9). Factors $1(48 \%)$ and $3(15 \%)$ are dominated by Nuttallides truempyi and Globocassidulina subglobosa, respectively, and are not shown here.

Factor 4 of the Site 884 data identifies a distinctive lower Eocene agglutinated biofacies (Fig. 8; 810-770 mbsf). Taxa with high loadings include Bathysiphon sp. (-73.5), Cribrostomoides subglobosus $(-31.4)$, Cyclammina sp. $(-27.1)$, and Spiroplectammina spectabilis $(-24.1)$. Although agglutinated species never comprise more than $60 \%$ of the assemblage, they are an important component of the lower Eocene fauna, as is apparent from the close relationship between Factor 4 and the relative abundance of agglutinated taxa (Fig. 8). Agglutinated taxa become less important near the lower/middle Eocene boundary.

The early Eocene agglutinated assemblage coexisted with a calcareous abyssal assemblage. As at Site 883 , Nuttallides truempyi dominates the calcareous biofacies, contributing up to $40 \%$ of the total assemblage. The dominance of Nuttallides truempyi is evident in Q-mode Factor 2 (Fig. 9), to which Nuttallides truempyi contributes high positive loadings (30.6).

Oridorsalis spp. contributes high negative loadings to Factor 2 (-88.0; Fig. 9), as this genus becomes increasingly important in the middle and upper Eocene ( 760-715 mbsf). Other important calcareous taxa included in Factor 2 are Globocassidulina subglobosa, Cibicidoides praemundulus and Gyroidinoides spp. However, unlike Oridorsalis, no clear shift in importance occurs in the latter taxa.

Although the stratigraphic ranges indicate that a benthic foraminifer turnover occurred near the Eocene/Oligocene boundary (Fig. 10; 13 species last occur between Samples 145-884B-75X-5, 140-145 $\mathrm{cm}$, and $-75 \mathrm{X}-3,128-133 \mathrm{~cm}$ ), we suspect that the upper Eocene and
Table 2. Age-model parameters, Sites 883 and 884.

\begin{tabular}{lll}
\hline \multicolumn{1}{c}{ Datum level } & $\begin{array}{c}\text { Age } \\
\text { (Ma) }\end{array}$ & $\begin{array}{c}\text { Depth } \\
\text { (mbsf) }\end{array}$ \\
\hline Site 883: & & \\
LO Reticulofenestra bisecta & 23.8 & 659.6 \\
LO Reticulofenstra umbilica & 33.8 & 670.0 \\
late Eocene $\delta^{18}$ O shift & $36.8 *$ & 710.9 \\
LO Chiasmolithus solitus & 42.3 & 712.8 \\
LO Discoaster sublodoensis & 49.7 & 754.4 \\
FO Nannotetrina spp. & 50.3 & 774.2 \\
FO Discoaster sublodoensis & 52.3 & 784.2 \\
FO Discoaster lodoensis & 55.0 & 812.0 \\
LO Fasciculithus spp. & 56.9 & 812.9 \\
Benthic extinction event & $58.1 * *$ & 813.2 \\
FO Discoaster mohleri & 60.2 & 821.4 \\
Site 884: & & \\
LO Reticulofenstra umbilica & 33.8 & 656.5 \\
LO Ericsonia formosa & 34.9 & 680.8 \\
late Eocene $\delta^{18}$ O shift & $36.8 *$ & 694.9 \\
LO Discoaster saipanensis & 37.7 & 695.0 \\
LO Aragonia aragonensis & 40.0 & 747.3 \\
LO Morozovella aragonensis & 45.9 & 762.4 \\
LO Morozovella caucasica & 51.9 & 767.3 \\
FO Cibicidoides grimsdalei & 54.0 & 800.4 \\
\hline
\end{tabular}

Notes: $\mathrm{LO}=$ last occurrence and $\mathrm{FO}=$ first occurrence. Single asterisk $(*)=$ age calibrated to Site 690 (Kennett and Stott, 1990); double asterisks $(* *)=$ age calibrated to Site 577 (Pak and Miller, 1992).

lower Oligocene sections are separated by an unconformity. We note the presence of sediment slumping and mixing as well as faunal reworking and suggest a hiatus between Samples 145-884B-75X-4, $75-80 \mathrm{~cm}$, and $-75 \mathrm{X}-3,128-133 \mathrm{~cm}$ ( $\sim 694.96 \mathrm{mbsf}$; see "Stratigraphy" section, this chapter).

\section{Early Eocene Faunal Depth Migrations}

Comparison of the stratigraphic ranges and factor analysis results of Sites 883 (lower bathyal) and 884 (abyssal) reveal that Nuttallides truempyi dominated the lower bathyal and abyssal realms in the northern Pacific during the early Eocene to middle middle Eocene as noted by Thomas (1992). During the middle middle Eocene, the relative abundance of Nuttallides truempyi decreased in the lower bathyal region, and was replaced by higher relative abundances of Oridorsalis, Globocassidulina subglobosa, Cibicidoides praemundulus, and Gyroidinoides. In the upper abyssal region, the relative abundance of Nuttallides truempyi became highly variable after the middle Eocene. Variations in the late Eocene percentage of $N$. truempyi appear to be in response to changes in Oridorsalis, G. subglobosa, and $C$. praemundulus or vice versa (Fig. 11). In the lower bathyal region, most species of heavily calcified buliminids last occur in the late middle Eocene. In the upper abyssal region, there is no clear pattern of buliminid last occurrences; Bulimina semicostata/jarvisi and Bulimina tuxpamensis last occur in a sample tentatively assigned to earliest late Eocene (Sample 145-884B-80X-5, 75-80 cm; 745.15 mbsf), whereas Bulimina impendens persists until the early Oligocene. In general, heavily calcified buliminids are less abundant in the upper abyssal than the lower bathyal region.

Among the less abundant taxa, we find that, during the early Eocene, there was a distinctive upper abyssal agglutinated assemblage, which persisted until the early/middle Eocene boundary. In the modern ocean, the distribution of agglutinated faunas is primarily controlled by the availability of calcium carbonate (Greiner, 1969). Because many forms utilize a solution-resistant organic cement, agglutinated foraminifers are favored in regions with more corrosive deep waters (see Gradstein and Berggren, 1981, for review). Our data indicate that Pacific deep waters were more corrosive during the early Eocene than the middle Eocene. This is consistent with reconstructions of the Eocene Pacific calcite compensation depth (van Andel et al., 1975).

Abyssaminids, including Abyssamina poagi, Abyssamina quadrata, and Quadrimorphina profunda, were present in both the lower bathyal and abyssal realms in the Pacific until the early/middle Eo- 

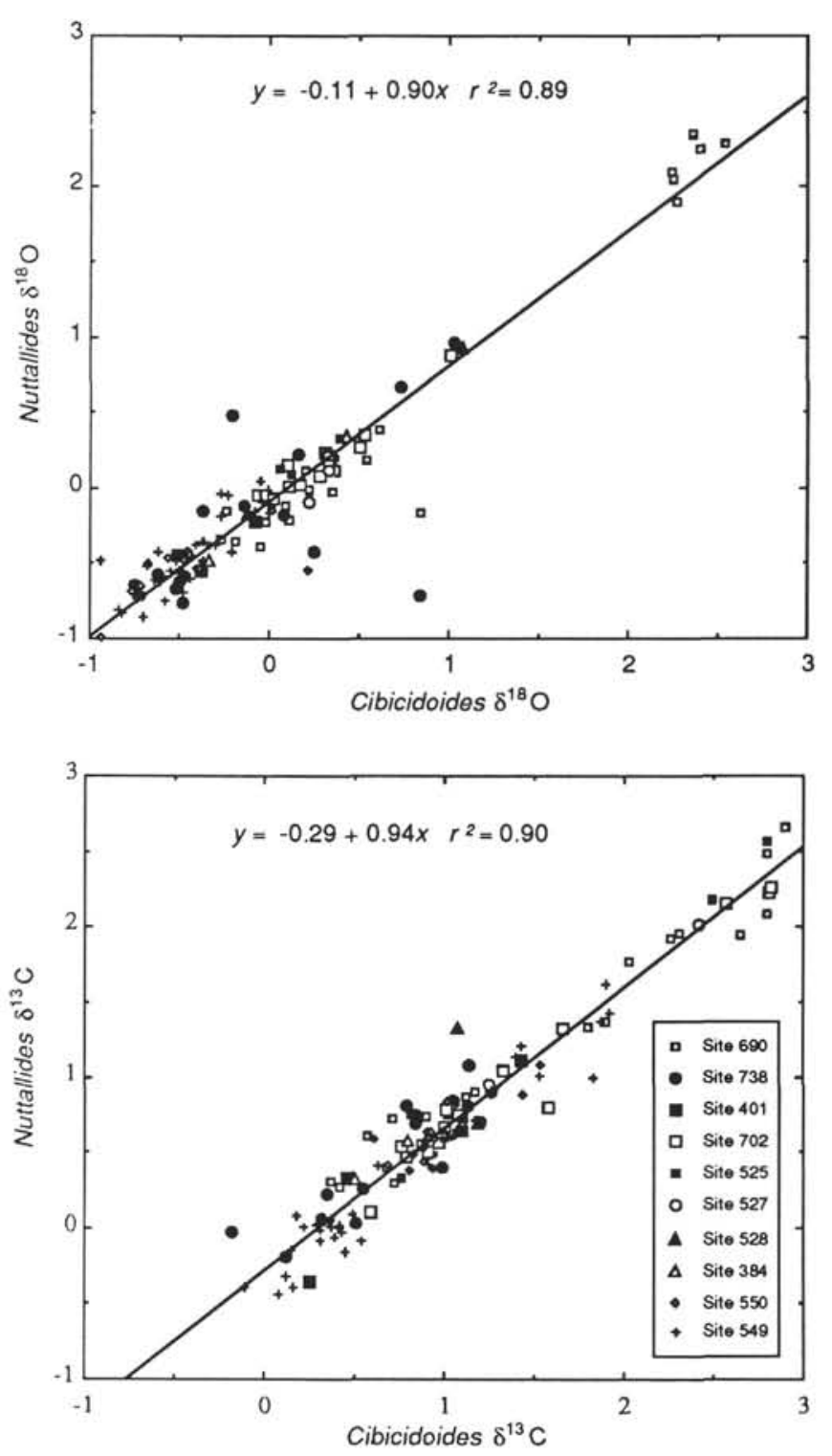

Figure 2. Paired Nuttallides truempyi and Cibicidoides spp. oxygen and carbon isotope analyses. Data is from Kennett and Stott (1990) (Site 690), Barrera and Huber (1991) (Site 738), Pak and Miller (1992) (Site 401), Katz and Miller (1991) (Sites 702 and 384), Shackleton et al. (1984) (Sites 525, 527, and 528), and Pak and Miller (unpubl. data) (Sites 550 and 549). Regression equations are drawn in the solid line.

cene boundary, at which time they became restricted to abyssal depths (Fig. 12). A similar migration event took place in the Atlantic, where abyssaminid species displayed wide bathymetric ranges in the early Eocene and gradually became restricted to deep-water sites in the middle Eocene (Tjalsma and Lohmann, 1983).

\section{Pacific Paleogene Isotope Record}

Together, Sites 883 and 884 provide relatively complete coverage of the Eocene isotopic record, providing a previously unattainable opportunity to monitor Pacific deep-water isotopic changes. The deep Pacific Ocean is the largest part of the global carbon budget, comprising $>50 \%$ of the modern reservoir (Baumgartner and Reichel, 1975). This was particularly true during the Eocene, when the Pacific was much larger than it is today. As a result, inferences regarding deep ocean circulation and ocean nutrient inventories rely on the Pacific record to approximate mean ocean values.
We compare Site 883 oxygen and carbon isotopic values to those at nearby Shatsky Rise Site $577\left(32^{\circ} 26.52^{\prime} \mathrm{N}, 157^{\circ} 43.40^{\prime} \mathrm{E}, 2675 \mathrm{~m}\right.$ present depth, Eocene paleodepth $\sim 2000 \mathrm{~m}$; Miller et al., 1987b; Pak and Miller, 1992). Site 577 provides a better late Paleocene to early Eocene record, but lacks middle-upper Eocene sediments (Miller et al., 1987b; Pak and Miller, 1992). In intervals of overlap, Site 883 $\delta^{18} \mathrm{O}$ and $\delta^{13} \mathrm{C}$ values are similar to Site 577 , indicating that the records may be combined to form a composite isotope record for the Pacific (Figs. 13, 14). Although we are concerned with the possibility of diagenesis at the deeply buried Detroit Seamount sites, the close agreement between Sites 883 and 577 (burial depth $\sim 150 \mathrm{~m}$ ) in both carbon and oxygen isotope values indicates that diagenesis has not been severe. If significant recrystallization had taken place, we would expect anomalously low $\delta^{18} \mathrm{O}$ values in the affected intervals (VernaudGrazzini et al., 1979). We see no such anomalous values throughout the studied section.

The composite Pacific record provides a relatively complete isotopic record for the late Paleocene to the early Oligocene. However, hiatuses were detected, such as a probable short gap across the Eocene/Oligocene boundary (see "Stratigraphy" section, this chapter). Additional hiatuses may be undetected because chronostratigraphic control on these sections is tentative (i.e., many of the calcareous marker taxa are dissolved and the sections lack magnetostratigraphic control). In addition, core recovery was poor in some intervals (e.g., Cores $145-883 \mathrm{~B}-83 \mathrm{X}$ to $-85 \mathrm{X})$. Despite these limitations, the composite $\delta^{18} \mathrm{O}$ and $\delta^{13} \mathrm{C}$ records (Figs. 13 and 14 ) provide a first approximation of Pacific deep-water isotopic changes.

Comparison between the Pacific $\delta^{18} \mathrm{O}$ record and the Atlantic benthic $\delta^{18} \mathrm{O}$ record (Miller et al., 1987a, fig. 1) indicates that both the amplitude and magnitude of the well-known isotopic shifts are preserved in the Pacific record. Benthic foraminifer $\delta^{18} \mathrm{O}$ values decreased from $\sim 0.5 \%$ in the late Paleocene to peak negative values of $1.0 \%$ in the early Eocene. A sharp $\delta^{18} \mathrm{O}$ increase of almost $1.0 \%$ occurred near the early/middle Eocene boundary. This increase marked the beginning of a gradual increase in $\delta^{18} \mathrm{O}$ that continued throughout the remainder of the Eocene. The $\delta^{18} \mathrm{O}$ values increased sharply by $\sim 1.5 \%$ across the Eocene/Oligocene boundary, reaching values of $\sim 1.8 \%$. No distinct increase is noted in the late middle Eocene, as reported in the Atlantic (Miller, 1992) and Southern oceans (Kennett and Stott, 1990; Katz and Miller, 1991; Miller, 1992), although this could be the result of poor coverage between ca. 41 and $39 \mathrm{Ma}$. In general, $\delta^{18} \mathrm{O}$ values appear to increase over this interval (Fig. 13).

Isotopic comparisons between Sites 883 and 884 provide an opportunity to examine depth-related differences in the Eocene deep Pacific. Specifically, we compared the late early Eocene and middle Eocene intervals of overlap between the lower bathyal Site 883 and the upper abyssal Site 884 (Figs. 13 and 14). During the middle Eocene there were no significant differences in either $\delta^{18} \mathrm{O}$ or $\delta^{13} \mathrm{C}$ of benthic foraminifer calcite, suggesting that the deep North Pacific (between 2000 $\mathrm{m}$ and $3400 \mathrm{~m}$ ) was not strongly stratified at this time. Comparisons between late early to early middle Eocene $(\sim 52.5-51 \mathrm{Ma})$ isotopes at Sites 883 and 884 show no significant differences in $\delta^{18} \mathrm{O}$. However, $\delta^{13} \mathrm{C}$ values at Site 884 were approximately $0.5 \%$ lower than at Site 883 , suggesting late early to early middle Eocene $(\sim 52-51.5 \mathrm{Ma})$ deep-water-mass stratification in the North Pacific.

We compare our composite Pacific isotope record to the Southern Ocean record of Site 690 (Maud Rise, $65^{\circ} 09.63^{\prime} \mathrm{S}, 1^{\circ} 12.30^{\prime} \mathrm{E}, 2925 \mathrm{~m}$ present depth, Eocene paleodepth $\sim 2000 \mathrm{~m}$; Kennett and Stott, 1990) to address possible Eocene deep-water circulation changes (Figs. 15, 16). We note that the chronology of the Eocene section at Site 690 is complicated by hiatuses, as well as the absence of planktonic foraminiferal index species. As a result, several different interpretations of the Eocene magnetics have been published (Kennett and Stott, 1990; Speiss, 1990; Thomas, 1990). These three interpretations differ in detail, but agree that all magnetic reversals between Chrons C22n and C25n are represented at Site 690. Based on calcareous nannofossil evidence, M.-P. Aubry et al. (unpubl. data, 1994) have made an inter- 


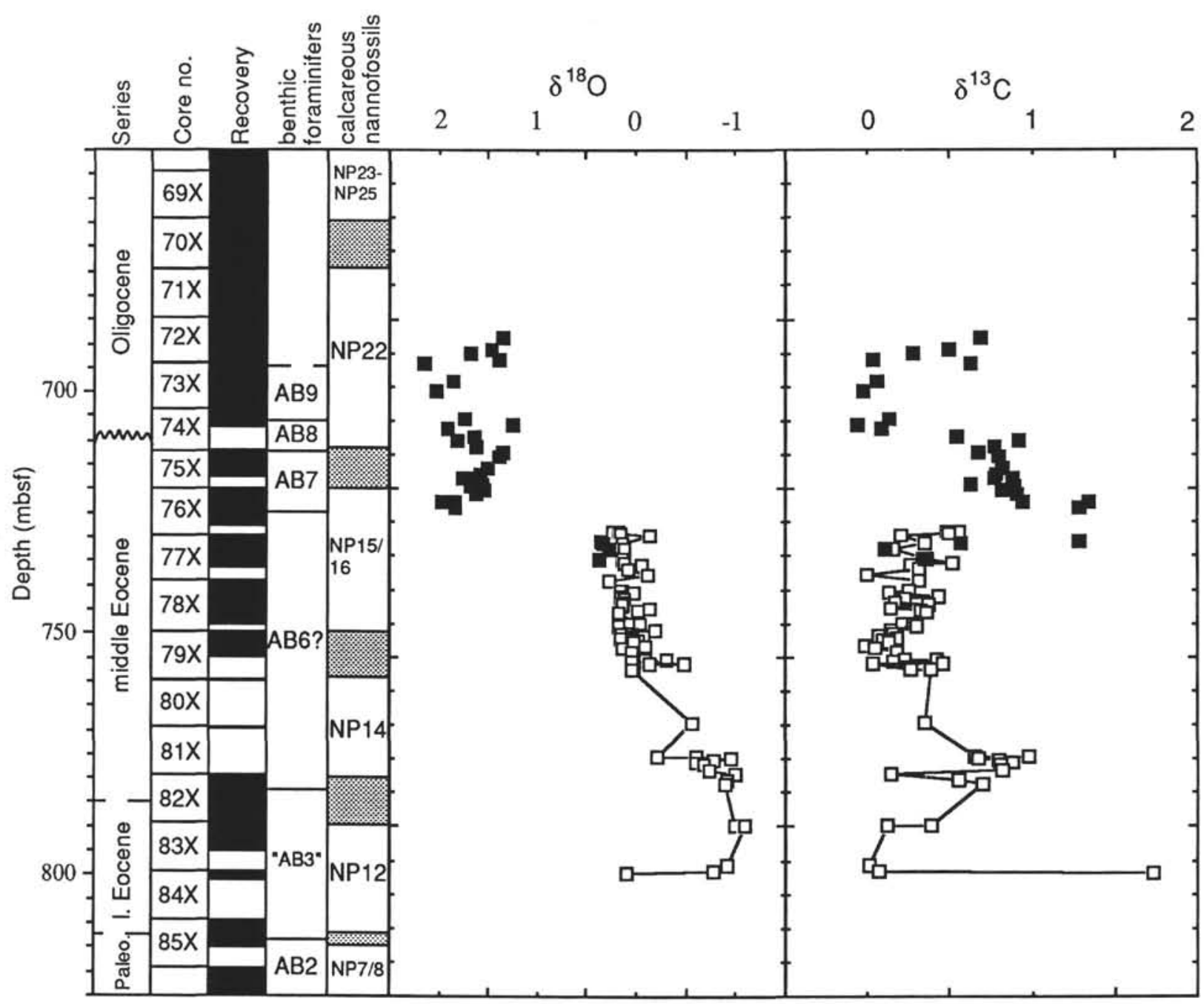

Figure 3. Stratigraphic summary of Hole 883B showing series, core recovery, benthic foraminifer zonation, calcareous nannofossil zonation, and uncorrected isotope data. Open squares represent data from Nuttallides truempyi; solid squares represent Cibicidoides spp.

pretation that is substantially different, in that they think that there are at least three major hiatuses in the lower Eocene section. An age model based on the M.-P. Aubry et al. (unpubl. data, 1994) stratigraphy (Table 3 ), indicates that very little lower Eocene section is preserved at Site 690 (Figs. 17, 18). If the Aubry et al. stratigraphy is correct, few comparisons can be made between the early Eocene Pacific and Southern Ocean isotopic records. An additional Southern Ocean record would be needed to validate some of the conclusions drawn here for the early Eocene. However, in this study we employ the published magnetostratigraphy-based age model of Kennett and Stott (1990) to compare the Pacific isotope record to the Southern Ocean record of Site 690.

During the late Paleocene (58-55 Ma), the Pacific and Southern oceans were remarkably similar in $\delta^{18} \mathrm{O}$, indicating similar deepwater temperatures and salinities. At the same time, the Pacific had lower $\delta^{13} \mathrm{C}$ values than did the Southern Ocean, supporting the conclusions of Pak and Miller (1992) that the Southern Ocean was the dominant source of deep water during the late Paleocene.

During the early Eocene, Pacific $\delta^{18} \mathrm{O}$ values were $0.5 \% 0-0.75 \%$ lower than Southern Ocean values, whereas $\delta^{13} \mathrm{C}$ values were $0.5 \%$ $1.0 \%$ lower. These data indicate that, although the deep Pacific and Southern oceans were bathed by different water masses, the Southern Ocean remained a source of colder and/or more saline deep waters. This is consistent with previous results (Miller et al., 1987b; Katz and Miller, 1991; Pak and Miller, 1992).
Table 3. Age-model parameters, Site 690, after stratigraphy of M.-P. Aubry (pers. comm., 1994).

\begin{tabular}{|c|c|c|}
\hline Datum level & $\begin{array}{l}\text { Age } \\
(\mathrm{Ma})\end{array}$ & $\begin{array}{l}\text { Depth } \\
\text { (mbsf) }\end{array}$ \\
\hline Base of C21n & 50.3 & 123.63 \\
\hline $\begin{array}{l}\text { Sediment missing: level between NP12 (reversed) and NP14a } \\
\text { (normal) }\end{array}$ & $\sim 53.7$ & 132.16 \\
\hline $\begin{array}{l}\text { Sediment missing: level younger than LO Tribrachiatus } \\
\text { contortus, older than LO Discoaster lodoensis, within C24nlr }\end{array}$ & -55.5 & 135.91 \\
\hline LO Tribrachiatus bramlettei & 56.7 & 149.2 \\
\hline Top of C25n & 58.6 & 185.47 \\
\hline
\end{tabular}

Note: $L O=$ last occurrence.

By providing constraints on the Pacific $\delta^{13} \mathrm{C}$ composition, the Detroit Seamount isotopic record allows the reconstruction of middle Eocene deep-water circulation. From the early middle to middle middle Eocene (49-44 Ma), $\delta^{18} \mathrm{O}$ values in the Pacific and Southern oceans were identical. Pacific $\delta^{13} \mathrm{C}$ values for the same interval were $0.5 \%$ - $0.75 \%$ lower than in the Southern Ocean. This relationship indicates that, as in the late Paleocene, the Southern Ocean represented the single dominant source of deep water during the early middle Eocene. 


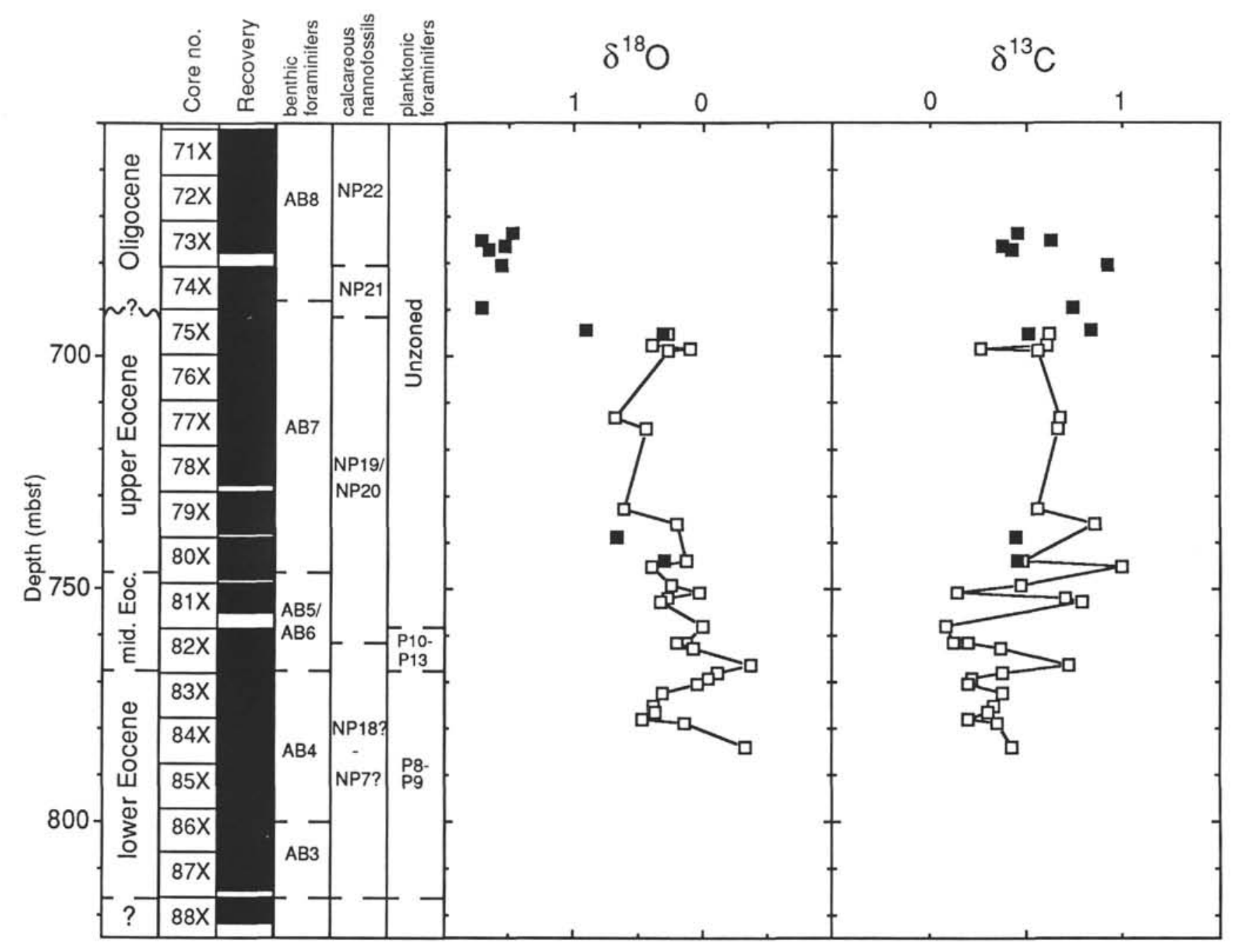

Figure 4. Stratigraphic summary of Hole 884B showing series, core recovery, benthic foraminifer zonation, calcareous nannofossil zonation, planktonic foraminifer zonation, and uncorrected isotope data. Open squares represent data from Nuttallides truempyi; solid squares represent Cibicidoides spp.

From the middle middle Eocene to the Eocene/Oligocene boundary $(46-36.5 \mathrm{Ma})$, the relationship between Pacific and Southern Ocean $\delta^{18} \mathrm{O}$ and $\delta^{13} \mathrm{C}$ returned to a configuration much like that of the early Eocene. Southern Ocean $\delta^{18} \mathrm{O}$ was $\sim 0.5 \%$ heavier than in the Pacific in both $\delta^{18} \mathrm{O}$ and $\delta^{13} \mathrm{C}$. These data indicate that the Southern Ocean was bathed by a cooler, more nutrient-depleted (i.e., closer to source) deep water than that which influenced the deep Pacific. It also implies that, although relatively warmer waters filled the Southern Ocean in the early middle Eocene, by the late middle Eocene Southern Ocean waters were again relatively cooler.

\section{DISCUSSION}

\section{Isotopes}

Carbon isotopic reconstructions indicate that the Southern Ocean was a source of deep water throughout the late Paleocene and most of the Eocene, with two possible exceptions: near the Paleocene/Eocene boundary, and near the early/middle Eocene boundary. At these two times, Pacific and Southern Ocean $\delta^{13} \mathrm{C}$ values converged. At all other times, Southern Ocean $\delta^{13} \mathrm{C}$ values were significantly $(0.5 \%-0.75 \%)$ higher than Pacific $\delta^{13} \mathrm{C}$ values. Given that the $\delta^{13} \mathrm{C}$ of foraminifer calcite decreases with increasing nutrients in deep water (Belanger et al., 1981; Graham et al., 1981), relatively high $\delta^{13} \mathrm{C}$ values indicate that the Southern Ocean was proximal to a more nutrient-depleted source of deep water than the Pacific.

A Southern Ocean/Pacific $\delta^{13} \mathrm{C}$ gradient does not necessarily imply that the two basins were influenced by different deep-water masses. The gradient may simply reflect aging along a circulation path from a nutrient-depleted source area to the more nutrient-enriched "end of the circulation route." However, oxygen isotopic results help constrain deep-water source areas. Unlike $\delta^{13} \mathrm{C}, \delta^{18} \mathrm{O}$ values are not affected by aging; a deep-water mass retains its $\delta^{18} \mathrm{O}$ signature unless its temperature and/or salinity is changed by mixing or diffusion. Deep-water $(2000-3400 \mathrm{~m}) \delta^{18} \mathrm{O}$ values between the Southern and North Pacific oceans were identical in the late Paleocene, early middle Eocene, and early Oligocene. This similarity supports the conclusion that the two basins were bathed by a water mass originating in a single source area proximal to the Southern Ocean.

Our comparisons between the Southern and Pacific ocean isotopic data support the results of previous studies. Isotopic reconstructions of Miller et al. (1987b), Katz and Miller (1991), and Pak and Miller (1992) all indicated that the late Paleocene Southern Ocean was a source of relatively nutrient-depleted, cool deep water. Previous studies (Kennett and Stott, 1990; Katz and Miller, 1991; Pak and Miller, 1992) suggested that the flux of Southern Ocean deep water was reduced or eliminated for a brief period in the latest Paleocene at the time of the much-heralded carbon isotopic excursion (see Kennett 


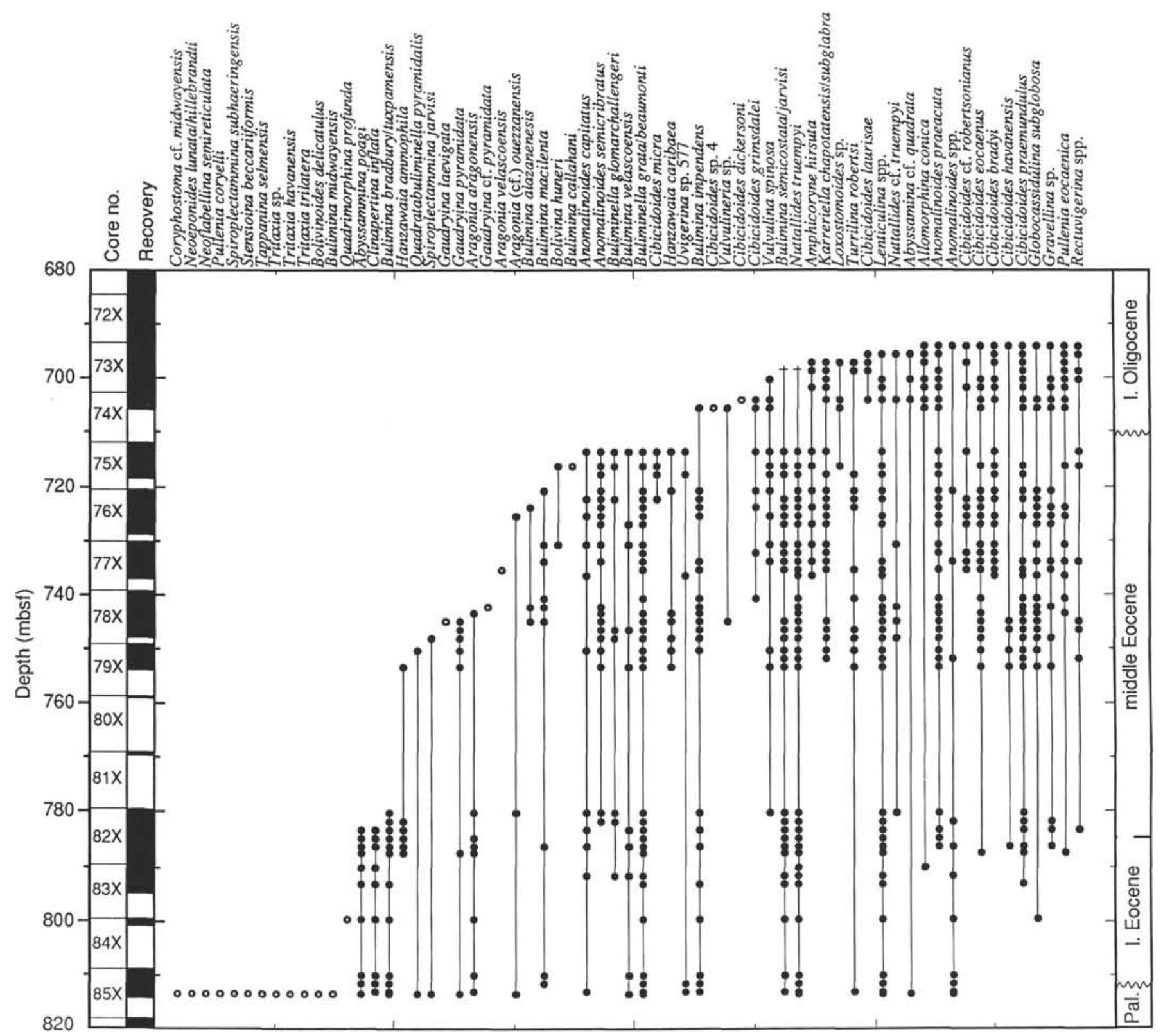

Figure 5. Stratigraphic range chart of benthic foraminifers from Hole 883B. Circles indicate the position of samples. Open circles indicate single occurrences of species.

and Stott, 1991, for discussion of the excursion). Although our data lack the resolution to address the isotopic excursion in particular, we provide evidence to support a major deep-water circulation change at this time.

Early Eocene (57-52 Ma) $\delta^{13} \mathrm{C}$ values indicate the continued supply of a nutrient-depleted Southern Ocean source of deep water. However, oxygen isotopic values diverged through this interval, with Southern Ocean values $\sim 0.5 \%$ higher than Pacific values. This relationship indicates that two sources of deep water must have operated simultaneously, providing different $\delta^{18} \mathrm{O}$ signatures to the Pacific and Southern oceans. Although the isotopic reconstructions suggest that the cool, nutrient-depleted source originated in the Southern Ocean, we cannot establish the source region of the relatively warm, nutrientenriched water mass that influenced the Pacific sites. We interpret that the North Pacific was not the source, because the relatively low $\delta^{13} \mathrm{C}$ signature suggests an "old" water mass. On the other hand, the relatively low $\delta^{18} \mathrm{O}$ signature suggests a warmer (or less saline) water than the Southern Ocean. Much attention has been given to the possibility of a source of warm saline deep water originating in the Tethyan region (Brass et al., 1982; Woodruff and Savin, 1989; Kennett and Stott, 1990; Pak and Miller, 1992). Our data support, but do not confirm, the presence of an early Eocene Tethyan deep water. Sites of Eocene age from within the Tethyan region are needed to identify Tethyan outflow.

The early/middle Eocene boundary is marked by a sharp $\delta^{18} \mathrm{O}$ increase. This increase is widely recognized (see Miller, 1992, for review) and represents the first step of the long Cenozoic cooling trend. Comparisons between the Pacific and Southern Ocean isotopic records suggest that the cooling step was accompanied by a deepwater circulation change. Concurrent with the cooling step, Southern and Pacific ocean $\delta^{18} \mathrm{O}$ and $\delta^{13} \mathrm{C}$ values converged. The $\delta^{13} \mathrm{C}$ convergence was short term (1 m.y.), after which the Southern OceanPacific gradient returned. The $\delta^{18} \mathrm{O}$ convergence lasted $\sim 6 \mathrm{~m}$.y. (52$46 \mathrm{Ma})$. In the middle middle Eocene ( $46 \mathrm{Ma})$, Southern Ocean 


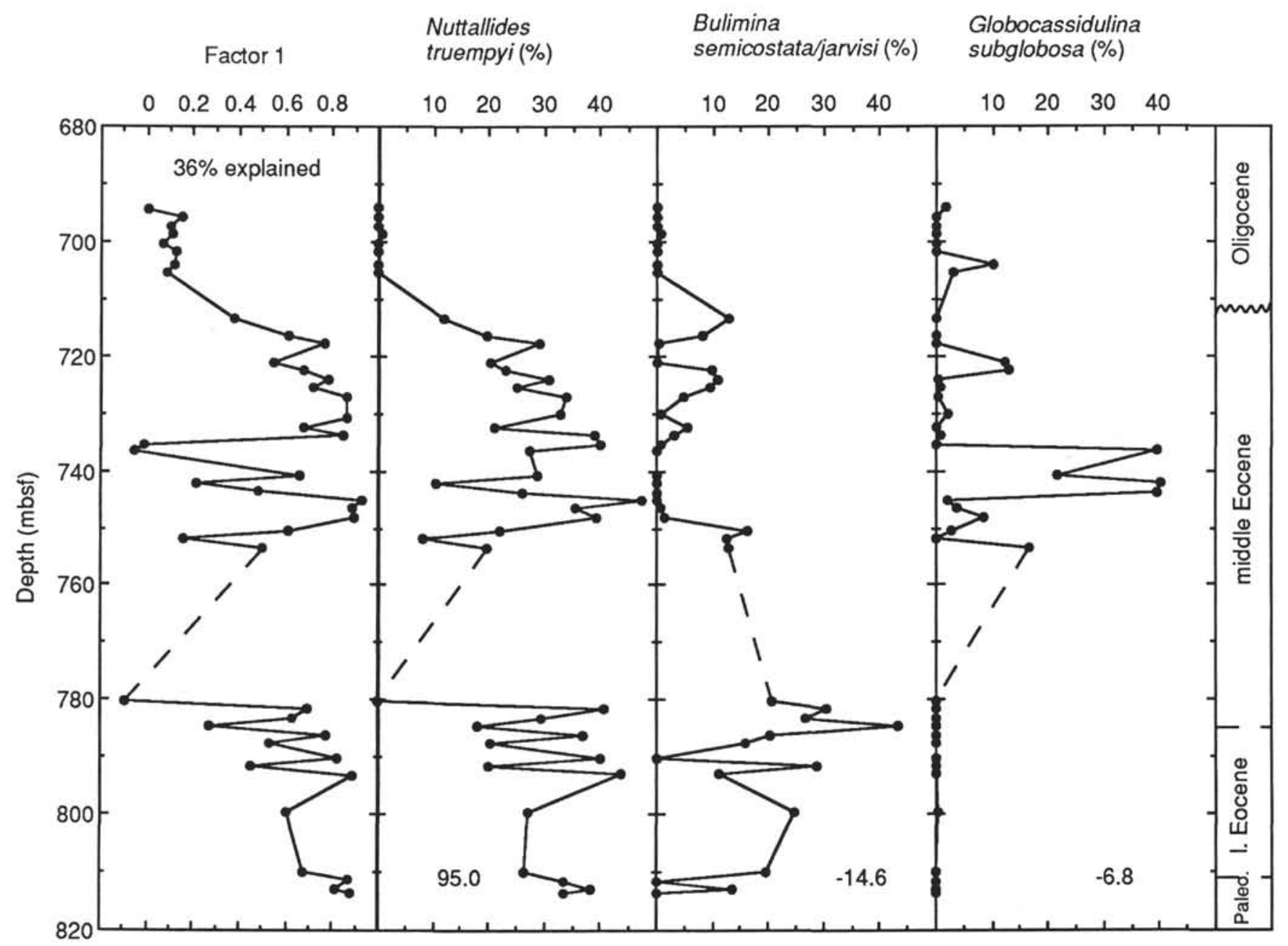

Figure 6. Q-mode Factor 1 of the Site 883 data set compared with the relative abundance (percentage) of species contributing to this component. Factor scores of each species are shown in the respective columns.

$\delta^{18} \mathrm{O}$ returned to values $\sim 0.5 \%$ higher than Pacific $\delta^{18} \mathrm{O}$. This relationship persisted until at least the Eocene/Oligocene boundary $(\sim 36.5 \mathrm{Ma})$.

On the basis of our Pacific-Southern Ocean isotopic comparisons, we suggest that the Eocene ocean alternated between two dominant circulation modes. The first, represented by the late Paleocene and early middle Eocene, is characterized by similar Pacific and Southern Ocean $\delta^{18} \mathrm{O}$ values, indicating a single source of deep water. Relatively high Southern Ocean $\delta^{13} \mathrm{C}$ values suggest that the source originated in or near the Southern Ocean. The second circulation mode is represented by the early Eocene and the middle middle to late Eocene, and is characterized by relatively high $\delta^{18} \mathrm{O}$ values in the Southern Ocean. This relationship suggests two sources of deep water: a cool source, originating in the Southern Ocean, and a warm source, probably originating in the mid-latitudes.

\section{Benthic Foraminifers}

Although previous studies (primarily from Atlantic sites; e.g., Tjalsma and Lohmann, 1983) have shown that benthic foraminifer faunal assemblages became increasingly depth stratified throughout the early and middle Eocene, the Detroit Seamount sites do not show such a stratification. Although the two sites are separated by approximately $1300 \mathrm{~m}$ in water depth, assemblages at the two sites were remarkably similar. Both sites show a middle Eocene change from assemblages dominated by Nuttallides truempyi to assemblages domi- nated by Oridorsalis, Globocassidulina subglobosa, Cibicidoides praemundulus, and Gyroidinoides spp.

Isotopic comparisons between Sites 883 and 884 support the concept of a relatively undifferentiated Eocene deep North Pacific. Where the sequences overlap (early/middle Eocene boundary, middle Eocene, earliest Oligocene), both oxygen and carbon isotopic values are virtually identical (Figs. 13 and 14). This indicates that the same water mass bathed regions of 2000 and $3300 \mathrm{~m}$ (middle Eocene paleodepths of Sites 883 and 884, respectively) in the North Pacific. Both the faunal and isotopic data suggest that there was little deep-water stratification in the middle to late Eocene and early Oligocene.

The one exception is the early Eocene, when the deep Site 884 was characterized by a distinctive agglutinated fauna not observed at Site 883. Similar deep-sea agglutinated faunas have been described from Paleogene abyssal sequences in the Labrador and North seas (Gradstein and Berggren, 1981; Miller et al., 1982; Kaminski et al., 1989). The Labrador and North sea faunas comprise diverse agglutinated assemblages in Maastrichtian through Eocene sediments. Their disappearance from the Labrador and North seas is attributed to the increase in bottom-water oxygenation and decrease in bottom-water corrosivity associated with the onset of vigorous abyssal circulation in the late Eocene/early Oligocene (Gradstein and Berggren, 1981; Miller et al., 1982; Kaminski et al., 1989).

Similarly, we suggest that Pacific deep waters were more corrosive during the early Eocene and less corrosive during the middle Eocene. This is supported by the carbonate percentage data, which 


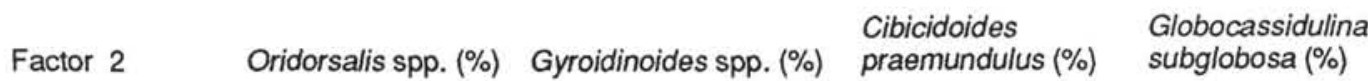

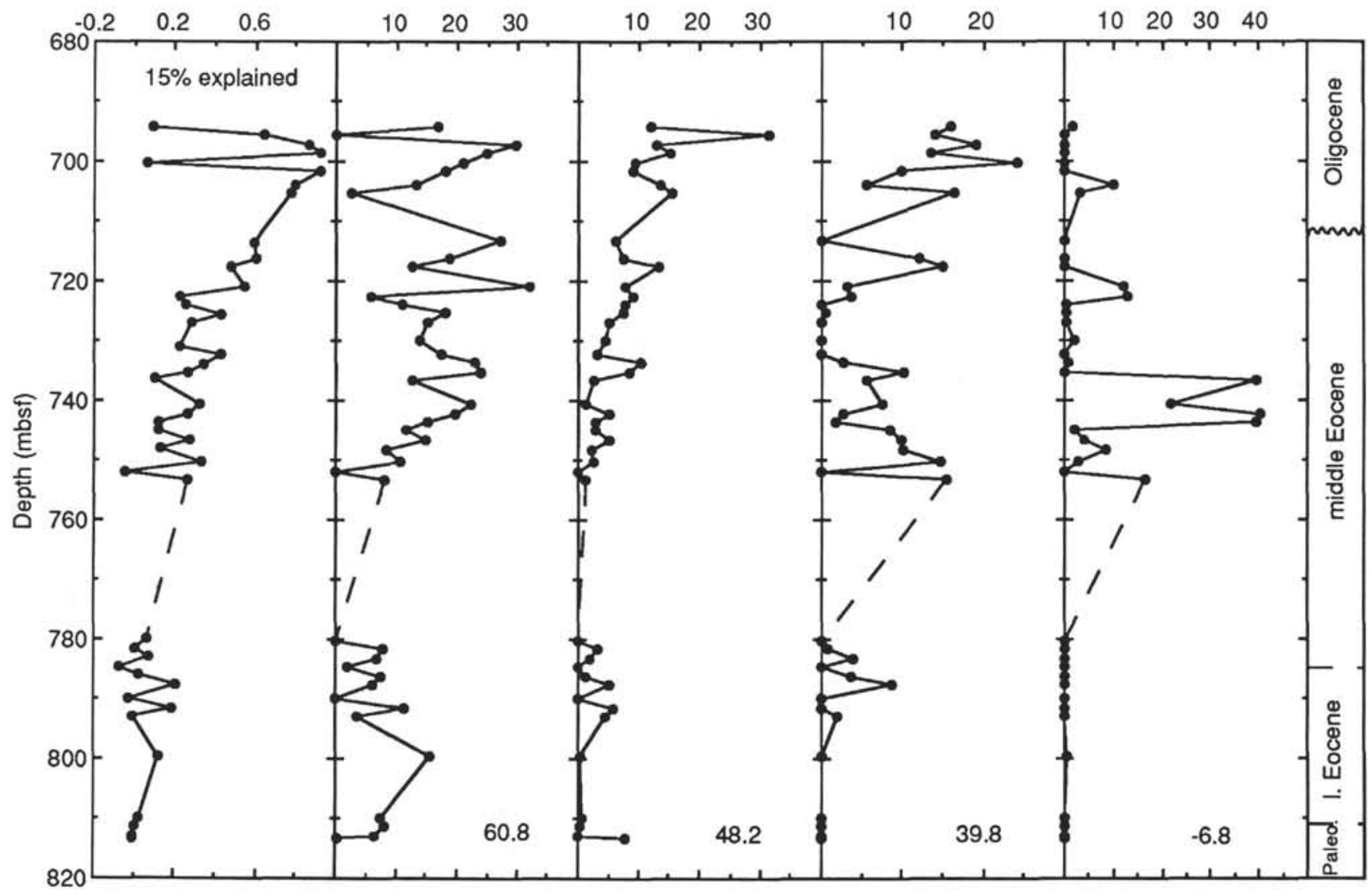

Figure 7. Q-mode Factor 2 of the Site 883 data set compared with the relative abundance (percentage) of species contributing to this component. Factor scores of each species are shown in the respective columns.

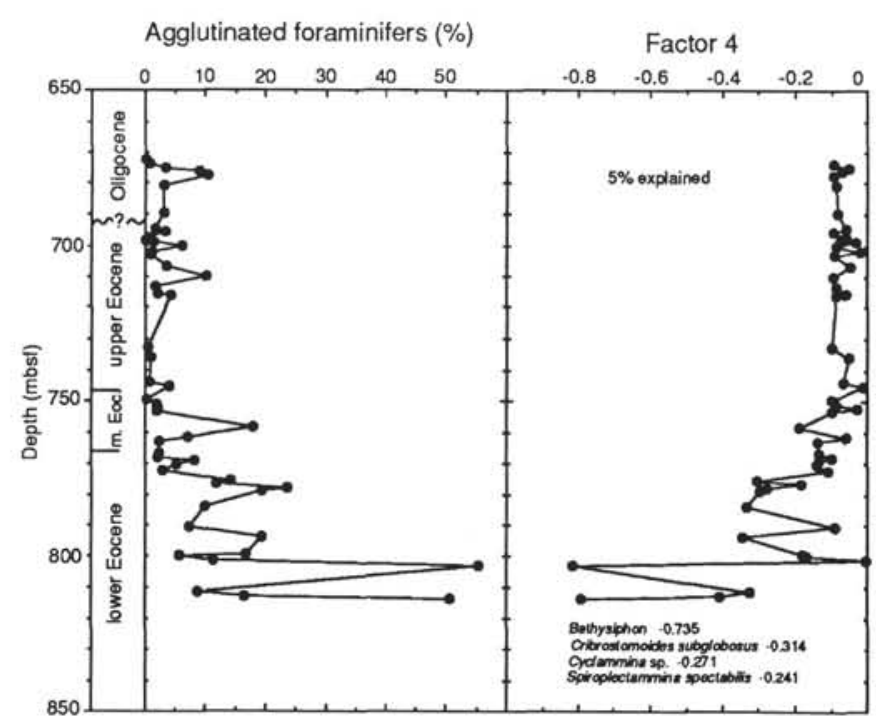

Figure 8. Relative abundance of agglutinated taxa at Site 884 compared with Q-mode Factor 4 of the Site 884 data set.

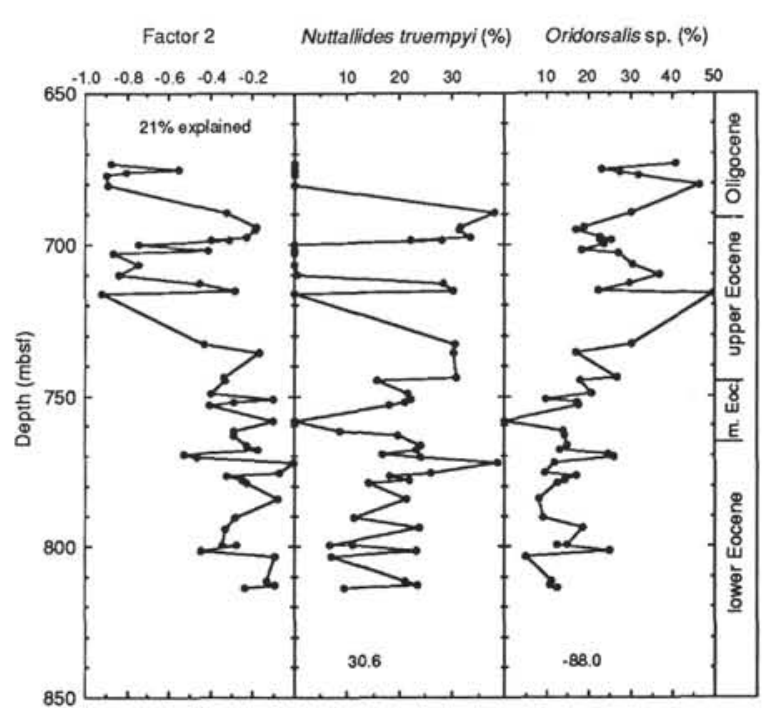

Figure 9. Q-mode Factor 2 of the Site 884 data set compared with the relative abundance (percentage) of species contributing to this component. Factor scores of each species are shown in the respective columns. 


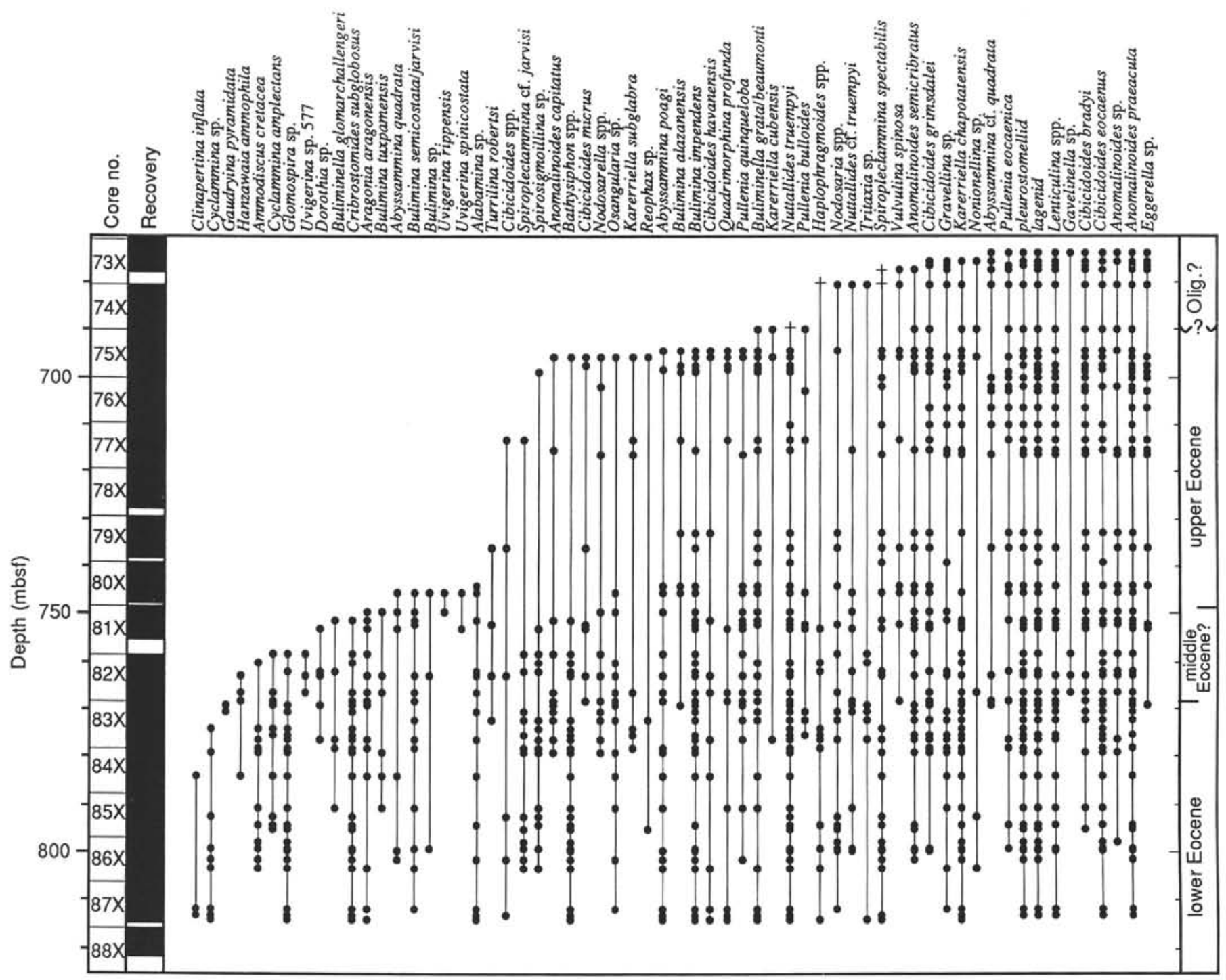

Figure 10. Stratigraphic range chart of benthic foraminifers from Site 884. Pluses indicate the presence of suspected reworked taxa.

show generally less carbonate in the early Eocene than in the younger section (Fig. 17). However, although very low carbonate values correlate with high percentages of agglutinated foraminifers, postdepositional dissolution is clearly not the sole factor controlling the early Eocene agglutinated assemblage, because (1) dissolution-resistant calcareous species (e.g., Gyroidinoides; Corliss and Honjo, 1981) are not preferentially preserved in this section; and (2) the percentage of early Eocene agglutinated taxa is high even when the percentage of carbonate is relatively high (Fig. 19). We think that the presence of the early Eocene agglutinated assemblage reflects the ability of these species to survive under more corrosive conditions, rather than postdepositional dissolution of calcareous species below the lysocline. The agglutinated assemblage decreased dramatically near the early/ middle Eocene boundary (Fig. 8). There was a simultaneous important benthic foraminiferal depth migration as abyssaminid species migrated from lower bathyal to abyssal depths (Fig. 12).

The faunal changes near the early/middle Eocene boundary are linked to deep-water changes. The first Cenozoic deep-water cooling step, as indicated by the benthic foraminifer $\delta^{18} \mathrm{O}$ record, was coincident with the faunal changes. In addition, the first Eocene convergence of Pacific and Southern ocean $\delta^{13} \mathrm{C}$ values, which we interpret as the change from a two-source to a one-source circulation system, also occurred at the early/middle Eocene boundary. We speculate that ben- thic foraminifer assemblages responded to both deep-water cooling and circulation change. After the early/middle Eocene cooling was more gradual, perhaps allowing the benthic fauna to become more gradually conditioned to the colder environment. Unfortunately, we do not yet have isotopic data from Site 884 that will enable us to determine the relative temperature of the deep site during the early Eocene. Nuttallides truempyi also apparently responded to the deep-water cooling trend. As noted by Miller et al. (1992) in subantarctic Site 702, the relative abundance of $N$. truempyi decreased during the early and middle Eocene in concert with the increase in $\delta^{18} \mathrm{O}$ (Fig. 20).

The absence of the agglutinated assemblage from the shallower site suggests that it preferred the presumably colder conditions of the abyssal region. Therefore, we cannot attribute its early/middle Eocene decline to deep-water cooling. Instead, we think that the faunal change was caused by changes in other deep-water parameters, probably decreased corrosivity, as the circulation system shifted from one mode to another.

Deep-water circulation changes have the potential to affect benthic foraminifer communities profoundly. The dramatic latest Paleocene benthic foraminifer extinction event was strongly linked to deep-water warming and a probable shift in circulation (e.g., Kennett and Stott, 1990; Thomas, 1990; Katz and Miller, 1991; Pak and Miller, 1992). The latest Paleocene faunal changes coincided with a 


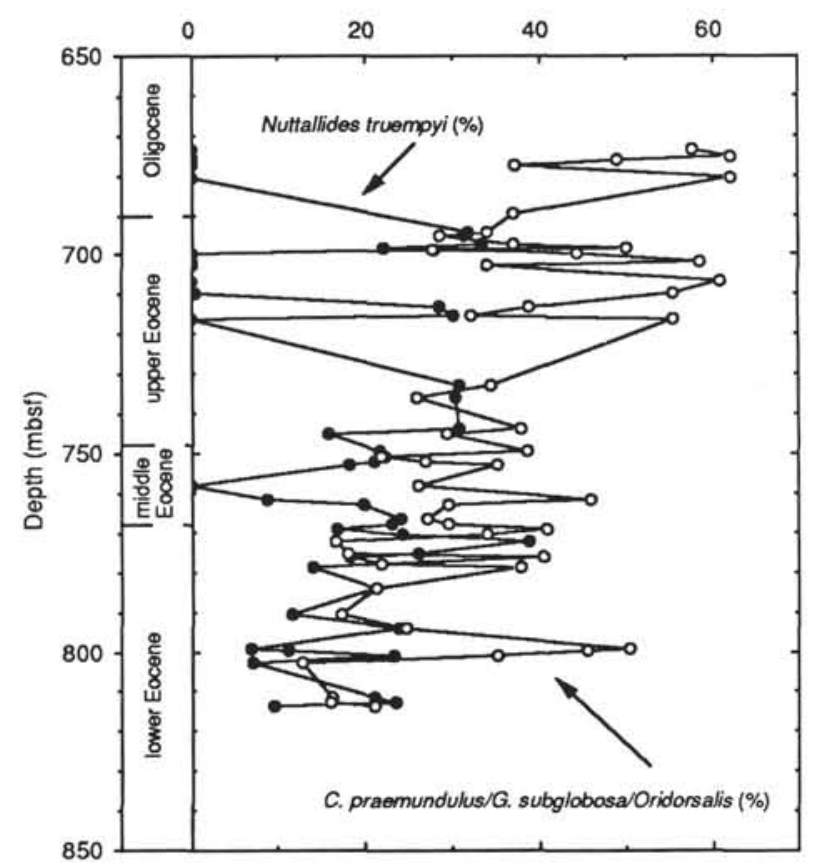

Figure 11. Comparison between the relative abundance of Nuttallides truempyi (solid circles) and the combined relative abundance of Cibicidoides praemundulus, Globocassidulina subglobosa, and Oridorsalis spp. (open circles) at Site 884 .

divergence of Pacific and Southern ocean $\delta^{18} \mathrm{O}$ values (Fig. 15), which can be interpreted as a shift from a one-source circulation mode to a two-source mode. We also note that the early Eocene was bracketed by anomalous short-term carbon isotopic convergences, which may herald circulation shifts, as well as by both benthic foraminifer faunal events and oxygen isotopic events.

\section{CONCLUSIONS}

1. Leg 145 Sites 883 and 884 provide the first detailed middle and upper Eocene isotope record from the North Pacific, although poor recovery and hiatuses still plague our records. Despite these limitations, these new data allow the construction of a composite Pacific $\delta^{18} \mathrm{O}$ record that is similar in both amplitude and magnitude to the Atlantic $\delta^{18} \mathrm{O}$ record. The Cenozoic cooling trend is punctuated by at least two strong $\delta^{18} \mathrm{O}$ increases: a step of $\sim 1.0 \%$ near the early middle Eocene boundary, and a step of $\sim 1.5 \%$ at the Eocene/Oligocene boundary. In addition, a third $\delta^{18} \mathrm{O}$ increase of lesser magnitude may be present near the middle/late Eocene boundary.

2. Eocene climatic cooling was accompanied by several shifts in deep-water circulation. Interbasinal isotopic comparisons indicate that the Eocene ocean alternated between two dominant circulation modes. During the early Eocene ( $57-52 \mathrm{Ma})$ and the middle middle Eocene to Oligocene ( $46-36.5 \mathrm{Ma})$, two sources of deep water were in operation: a cool, nutrient-depleted source originating in the Southern Ocean and a warmer, more nutrient-enriched source probably originating in the subtropics. However, during the early to middle middle Eocene ( $52-46 \mathrm{Ma}$ ), the deep North Pacific was influenced by a single source of deep water originating in the Southern Ocean. Our data indicate that, although there were times of probable mid-latitude deep-water production, the Southern Ocean remained a source region throughout most of the Paleogene.

3. North Pacific faunal changes indicate that early Eocene deep waters $(2000-3300 \mathrm{~m})$ were distinctly depth-stratified. However, isotopic and faunal changes indicate that there was little deep-watermass stratification in the middle Eocene. This is in contrast to Atlantic foraminifer faunal studies (i.e., Tjalsma and Lohmann, 1983) which

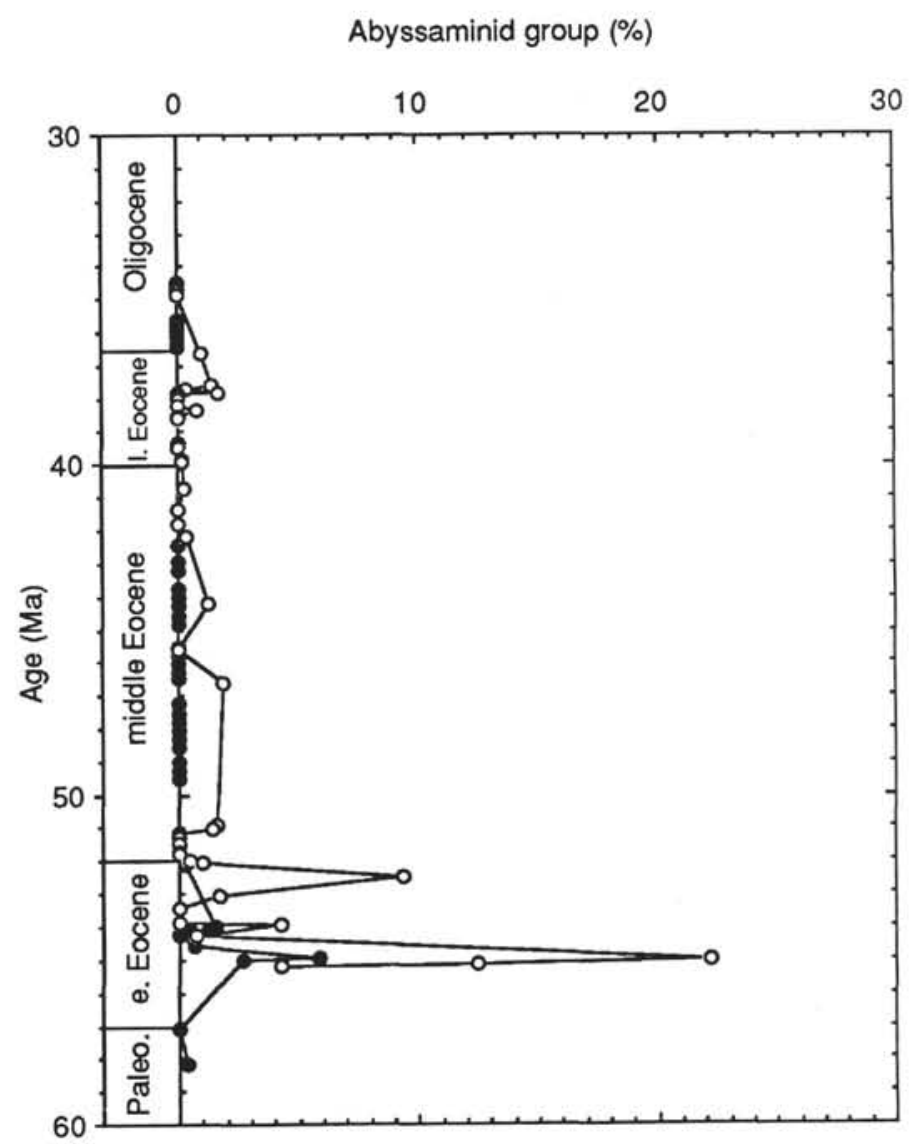

Figure 12. Comparison of the relative abundance of abyssaminid group foraminifers (Abyssamina poagi, Quadrimorphina profunda, and Abyssamina quadrata) at Sites 883 (solid circles) and 884 (open circles), showing the migration of these taxa from the upper abyssal to the lower bathyal realm near the early/middle Eocene boundary.

suggest that benthic foraminifers became progressively depth-stratified after the latest Paleocene extinction event.

4. Changes in Eocene benthic foraminifer assemblages were related to both deep-water cooling and circulation events. The early/middle Eocene migration of abyssaminid species from lower bathyal to abyssal depths coincided with the first Cenozoic cooling step. Also, the relative abundance of Nuttallides truempyi decreased in response to long-term Eocene cooling. Finally, the disappearance of the early Eocene agglutinated assemblage from the North Pacific coincided with an inferred shift in circulation from a two-source to a one-source mode.

\section{ACKNOWLEDGMENTS}

Reviews by E. Thomas and J. Kennett greatly improved the manuscript. We thank M. Katz, L. Beaufort and M.-P. Aubry for helpful discussions. This work was partially supported by a JOI/USSAC shipboard Ocean Drilling Fellowship and by JOI/USSAC grant 14520713. This is Lamont-Doherty Earth Observatory contribution number 5350 .

\section{REFERENCES}

Aubry, M.-P., Berggren, W.A., Kent, D.V., Flynn, J.J., Klitgord, K.D., Obradovich, J.D., and Prothero, D.R., 1988. Paleogene geochronology: an integrated approach. Paleoceanography, 3:707-742.

-Abbreviations for names of organizations and publications in ODP reference lists follow the style given in Chemical Abstracts Service Source Index (published by American Chemical Society). 
Barrera, E., and Huber, B.T., 1991. Paleogene and early Neogene oceanography of the southern Indian Ocean: Leg 119 foraminifer stable isotope results, In Barron, J., Larsen, B., et al., Proc. ODP, Sci. Results, 119 : College Station, TX (Ocean Drilling Program), 693-717.

Barron, E.J., 1987. Eocene equator-to-pole surface ocean temperatures: a significant climate problem. Paleoceanography, 2:729-739.

Barron, E.J., and Peterson, W.H., 1991. The Cenozoic ocean circulation based on ocean General Circulation Model results. Palaeogeogr, Palaeoclimatol., Palaeoecol., 83:1-28.

Barron, J., Larsen, B., and Baldauf, J.G., 1991. Evidence for late Eocene to early Oligocene Antarctic glaciation and observations on late Neogene glacial history of Antarctica: results from Leg 119. In Barron, J., Larsen, B., et al., Proc. ODP, Sci. Results, 119: College Station, TX (Ocean Drilling Program), 869-891.

Baumgartner, A., and Reichel, P., 1975. The World Water Balance: New York (Elsevier).

Belanger, P.E., Curry, W.B., and Matthews, R.K., 1981. Core-top evaluation of benthic foraminiferal isotopic ratios for paleoceanographic interpretations. Palaeogeogr., Palaeoclimatol., Palaeoecol., 33:205-220.

Berger, W.H., and Winterer, E.L., 1974. Plate stratigraphy and the fluctuating carbonate line. In Hsü, K.J., and Jenkyns, H.C. (Eds.), Pelagic Sediments on Land and Under the Sea. Spec. Publ. Int. Assoc. Sedimentol., 1:11-48.

Berggren, W.A., Kent, D.V., and Flynn, J.J., 1985. Jurassic to Paleogene: Part 2. Paleogene geochronology and chronostratigraphy. In Snelling, N.J. (Ed.), The Chronology of the Geological Record. Geol. Soc. London Mem., 10:141-195.

Berggren, W.A., and Miller, K.G., 1989. Cenozoic bathyal and abyssal calcareous benthic foraminiferal zonation. Micropaleontology, 35:308-320.

Brass, G.W., Southam, J.R., and Peterson, W.H., 1982. Warm saline bottom water in the ancient ocean. Nature, 296:620-623.

Broecker, W.S., and Denton, G.H., 1989. The role of ocean-atmosphere reorganizations in glacial cycles. Geochim. Cosmochim. Acta, 53:2465-2501.

Cande, S.C., and Kent, D.V., 1992. A new geomagnetic polarity time-scale for the late Cretaceous and Cenozoic. J. Geophys, Res., 97:13917-13951.

Chamberlin, T.C., 1906. On a possible reversal of deep-sea circulation and its influence on geologic climates. J. Geol., 14:363-373.

Corliss, B.H., and Honjo, S., 1981. Dissolution of deep-sea benthonic foraminifera. Micropaleontology, 27:356-378.

Corliss, B.H., and Keigwin. L.D., 1986. Eocene-Oligocene paleoceanography. In Hsü, K.J. (Ed.), Mesozoic and Cenozoic Oceans. Am. Geophys. Union, Geodyn. Ser., 15:101-118.

Detrick, R.S., Sclater, J.G., and Thiede, J., 1977. The subsidence of aseismic ridges. Earth Planet. Sci. Lett., 34:185-198.

Gradstein, F.M., and Berggren, W.A., 1981. Flysch-type agglutinated foraminifera and the Maastrichtian to Paleogene history of the Labrador and North seas. Mar. Micropaleontol., 6:211-268.

Graham, D.W., Corliss, B.H., Bender, M.L., and Keigwin, L.D., Jr., 1981. Carbon and oxygen isotopic disequilibria of Recent deep-sea benthic foraminifera. Mar. Micropaleontol., 6:483-497.

Greiner, G.O., 1969. Recent benthonic foraminifera: environmental factors controlling their distribution. Nature, 223:168-170.

Jones, G.A., and Kaiteris, P., 1983. A vacuum-gasometric technique for rapid and precise analysis of calcium carbonate in sediments and soils. $J$. Sediment. Petrol., 53:655-660.

Kaminski, M.A., Gradstein, F.M., and Berggren, W.A., 1989. Paleogene benthic foraminifer biostratigraphy and paleoecology at Site 647, Southern Labrador Sea. In Srivastava, S.P., Arthur, M.A., Clement, B., et al., Proc. ODP, Sci. Results, 105: College Station, TX (Ocean Drilling Program), 705-730.

Katz, M.E., and Miller, K.G., 1991. Early Paleogene benthic foraminiferal assemblages and stable isotopes in the Southern Ocean. In Ciesielski, P.F. Kristoffersen, Y., et al., Proc. ODP, Sci. Results, 114: College Station, TX (Ocean Drilling Program), 481-512.

Keigwin, L.D., and Corliss, B.H., 1986. Stable isotopes in late middle Eocene to Oligocene foraminifera. Geol. Soc. Am. Bull., 97:335-345.

Keigwin, L.D., Jr., 1980. Palaeoceanographic change in the Pacific at the Eocene-Oligocene boundary. Nature, 287:722-725.

Kennett, J.P., and Stott, L.D., 1990. Proteus and Proto-oceanus: ancestral Paleogene oceans as revealed from Antarctic stable isotopic results: ODP Leg 113. In Barker, P.F., Kennett, J.P., et al., Proc. ODP, Sci. Results, 113: College Station, TX (Ocean Drilling Program), 865-880.

, 1991. Abrupt deep-sea warming, paleoceanographic changes and benthic extinctions at the end of the Palaeocene. Nature, 353:225-229.
Mead, G.A., Hodell, D.A., and Cielsielski, P.F., 1993. Late Eocene to Oligocene vertical isotopic gradients in the South Atlantic: implications for warm saline deep water. In Kennett, J.P., and Warnke, D. (Eds.), The Antarctic Paleoenvironment: A Perspective on Global Change. Am. Geophys. Union, Antarc. Res. Ser., 60:27-48.

Miller, K.G., 1983. Eocene-Oligocene paleoceanography of the deep Bay of Biscay: benthic foraminiferal evidence. Mar. Micropaleontol., 7:403-440. 1992. Middle Eocene to Oligocene stable isotopes, climate, and deep-water history: the Terminal Eocene Event? In Prothero, D., and Berggren, W.A. (Eds.), Eocene-Oligocene Climatic and Biotic Evolution: Princeton, NJ (Princeton Univ. Press), 160-177.

Miller, K.G., Fairbanks, R.G., and Mountain, G.S., 1987a. Tertiary oxygen isotope synthesis, sea-level history, and continental margin erosion. Paleoceanography, 2:1-19.

Miller, K.G., Gradstein, F.M., and Berggren, W.A., 1982. Late Cretaceous to early Tertiary agglutinated benthic foraminifera in the Labrador Sea. Micropaleontology, 28:1-30.

Miller, K.G., Janecek, T.R., Katz, M.E., and Keil, D.J., 1987b. Abyssal circulation and benthic foraminiferal changes near the Paleocene/Eocene boundary. Paleoceanography, 2:741-761.

Miller, K.G., Katz, M.E., and Berggren, W.A., 1992. Cenozoic deep-sea benthic foraminifera: a tale of three turnovers. In BENTHOS '90: Sendai (Tokai Univ. Press), 67-75.

Müller-Merz, E., and Oberhänsli, H., 1991. Eocene bathyal and abyssal benthic foraminifera from a South Atlantic transect at $20-30^{\circ}$ S. Palaeogeogr., Palaeoclimatol., Palaeoecol., 83:117-171.

Oberhänsli, H., McKenzie, J., Toumarkine, M., and Weissert, H., 1984. A paleoclimatic and paleoceanographic record of the Paleogene in the central South Atlantic (Leg 73, Sites 522, 523, and 524). In Hsü, K.J., LaBrecque, J.L., et al., Init. Repts. DSDP, 73: Washington (U.S. Govt. Printing Office), 737-747.

Pak, D.K., and Miller, K.G., 1992. Paleocene to Eocene benthic foraminiferal isotopes and assemblages: implications for deepwater circulation. Paleoceanography, 7:405-422.

Rea, D.K., Basov, I.A., Janecek, T.R., Palmer-Julson, A., et al., 1993. Proc. ODP, Init. Repts., 145: College Station, TX (Ocean Drilling Program).

Savin, S.M., 1977. The history of the Earth's surface temperature during the past 100 million years. Annu. Rev. Earth. Planet Sci., 5:319-355.

Savin, S.M., Douglas, R.G., and Stehli, F.G., 1975. Tertiary marine paleotemperatures. Geol. Soc. Am. Bull., 86:1499-1510.

Sclater, J.G., Abbot, D., and Thiede, J., 1977. Paleobathymetry and sediments of the Indian Ocean. In Heirtzler, J., Bolli, H.M., Davies, T.A., Saunders, J.B., and Sclater, J.G. (Eds.), Indian Ocean Geology and Biostratigraphy. Am. Geophys. Union, 25-59.

Shackleton, N., and Boersma, A., 1981. The climate of the Eocene ocean. J. Geol. Soc. London, 138:153-157.

Shackleton, N.J., 1986. Paleogene stable isotope events. Palaeogeogr., Palaeoclimatol., Palaeoecol., 57:91-102.

Shackleton, N.J., Hall, M.A., and Boersma, A., 1984. Oxygen and carbon isotope data from Leg 74 foraminifers. In Moore, T.C., Jr., Rabinowitz, P.D., et al., Init. Repts. DSDP, 74: Washington (U.S. Govt. Printing Office), 599-644.

Shackleton, N.J., and Kennett, J.P., 1975. Paleotemperature history of the Cenozoic and the initiation of Antarctic glaciation: oxygen and carbon isotope analyses in DSDP Sites 277, 279, and 281. In Kennett, J.P., Houtz, R.E., et al., Init. Repts. DSDP, 29: Washington (U.S. Govt. Printing Office), 743-755.

Spiess, V., 1990. Cenozoic magnetostratigraphy of Leg 113 drill sites, Maud Rise, Weddell Sea, Antarctica. In Barker, P.F., Kennett, J.P., et al., Proc. ODP, Sci. Results, 113: College Station, TX (Ocean Drilling Program), 261-315.

Thomas, E., 1990. Late Cretaceous through Neogene deep-sea benthic foraminifers (Maud Rise, Weddell Sea, Antarctica). In Barker, P.F., Kennett, J.P., et al., Proc. ODP, Sci. Results, 113: College Station, TX (Ocean Drilling Program), 571-594.

- 1992. Cenozoic deep-sea circulation: evidence from deep-sea benthic foraminifera. In Kennett, J.P., and Warnke, D. (Eds.), The Antarctic Paleoenvironment: A Perspective on Global Change. Am. Geophys. Union, Antarct. Res, Ser., 56:141-165.

Tjalsma, R.C., and Lohmann, G.P., 1983. Paleocene-Eocene bathyal and abyssal benthic foraminifera from the Atlantic Ocean. Micropaleontol. Spec. Publ., 4. 
van Andel, T.H., Heath, G.R., and Moore, T.C., Jr., 1975. Cenozoic history and paleoceanography of the central equatorial Pacific Ocean: a regional synthesis of Deep Sea Drilling Project data. Mem.-Geol. Soc. Am., 143.

van Morkhoven, F.P.C.M., Berggren, W.A., and Edwards, A.S., 1986. Cenozoic cosmopolitan deep-water benthic foraminifera. Bull. Cent. Rech. Explor-Prod. Elf-Aquitaine, Mem. 11.

Vergnaud Grazzini, C., Müller, C., Pierre, C., Létolle, R., and Peypouquet, J.P., 1979. Stable isotopes and Tertiary paleontological paleoceanography in the northeast Atlantic. In Montadert, L., Roberts, D.G., et al., Init. Repts. DSDP, 48: Washington (U.S. Govt. Printing Office), 475-491.

Wise, S.W., Gombos, A.M., and Muza, J.P., 1985. Cenozoic evolution of polar water masses, southwest Atlantic Ocean. In Hsü, K.J., and Weissert, H.J.

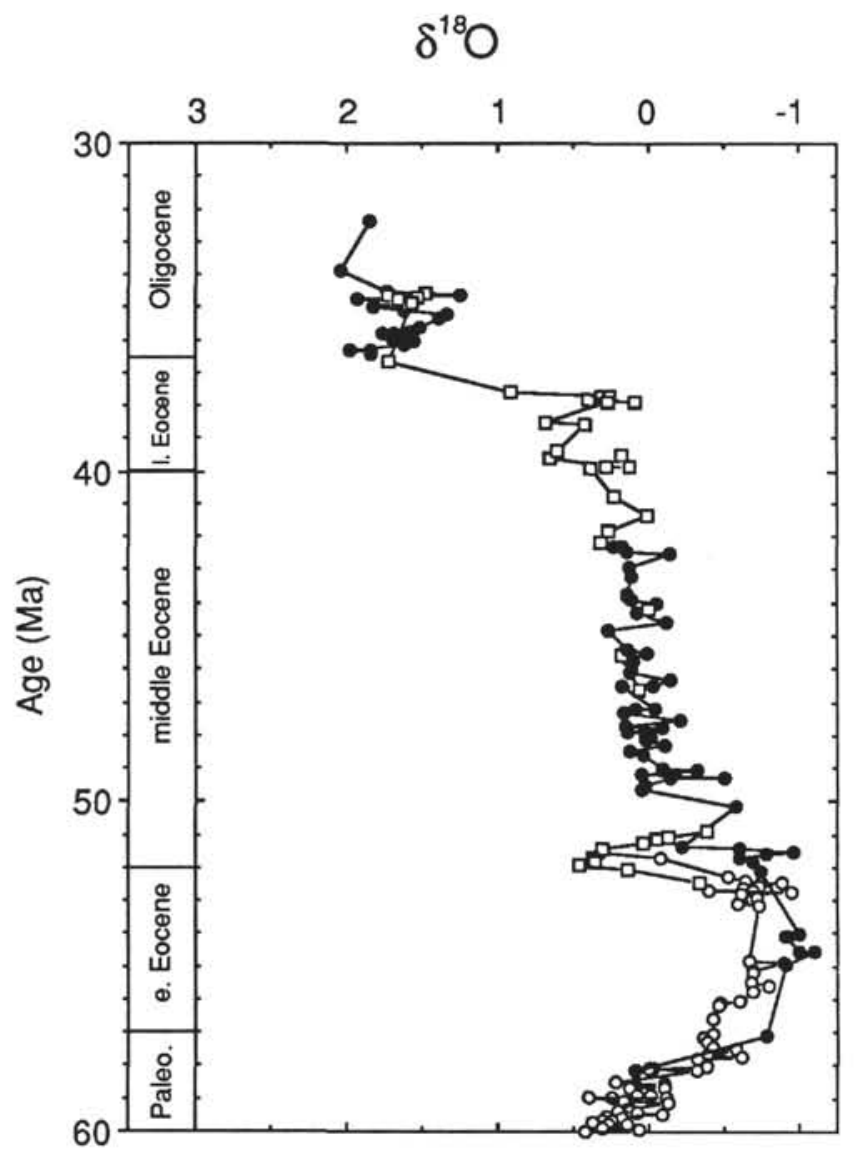

Figure 13. Oxygen isotopic records of Pacific Sites 883 (solid circles), 884 (squares), and 577 (open circles); data from Pak and Miller (1992).
(Eds.), South Atlantic Paleoceanography: Cambridge (Cambridge Univ. Press), 283-324.

Wolfe, J.A., 1978. A paleobotanical interpretation of Tertiary climates in the Northern Hemisphere. Am. J. Sci., 66:694-703.

Woodruff, F., and Savin, S.M., 1989. Miocene deepwater oceanography. Paleoceanography, 4:87-140.

Zachos, J.C., Stott, L.D., and Lohmann, K.C., 1994. Evolution of early Cenozoic marine temperatures. Paleoceanography, 9:353-387.

Date of initial receipt: 4 April 1994

Date of acceptance: 18 August 1994

Ms 145SR-121

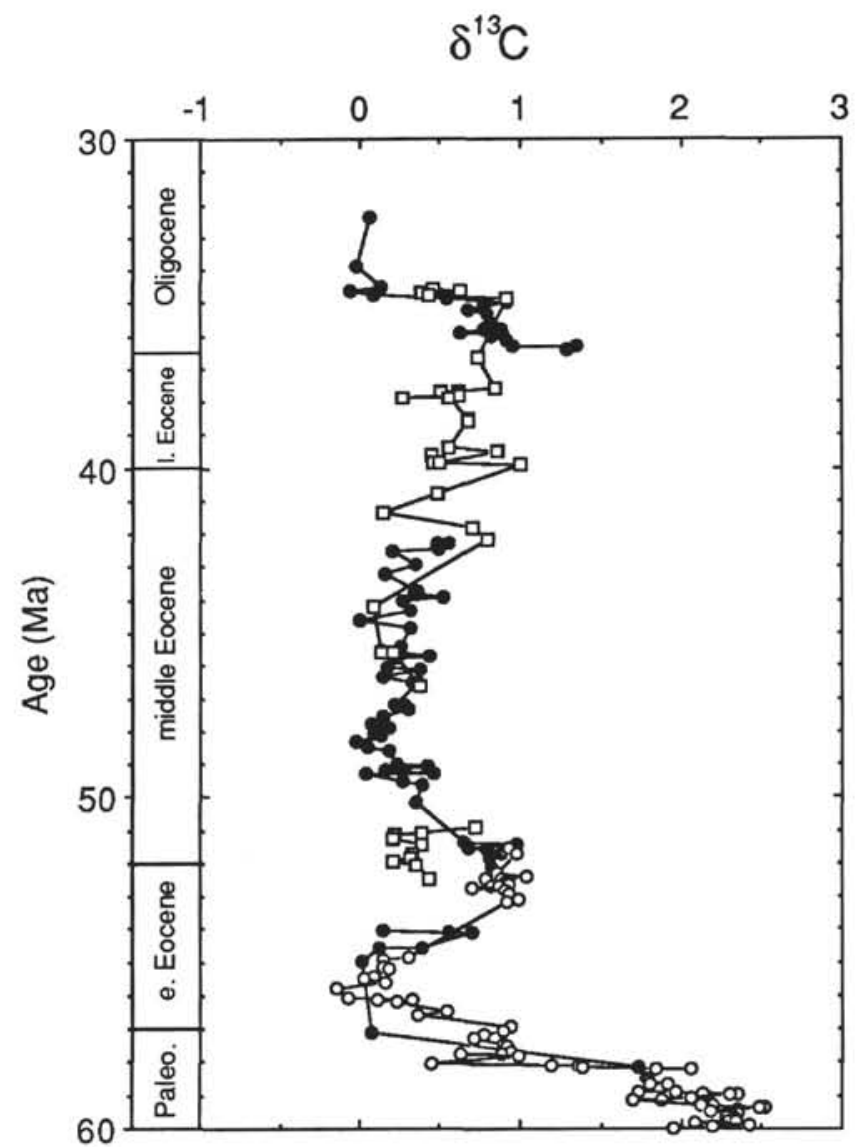

Figure 14. Carbon isotopic records of Pacific Sites 883 (solid circles), 884 (squares), and 577 (open circles); data from Pak and Miller (1992). Nuttallides truempyi data are corrected by $0.3 \%$ for comparison with Cibicidoides data. 


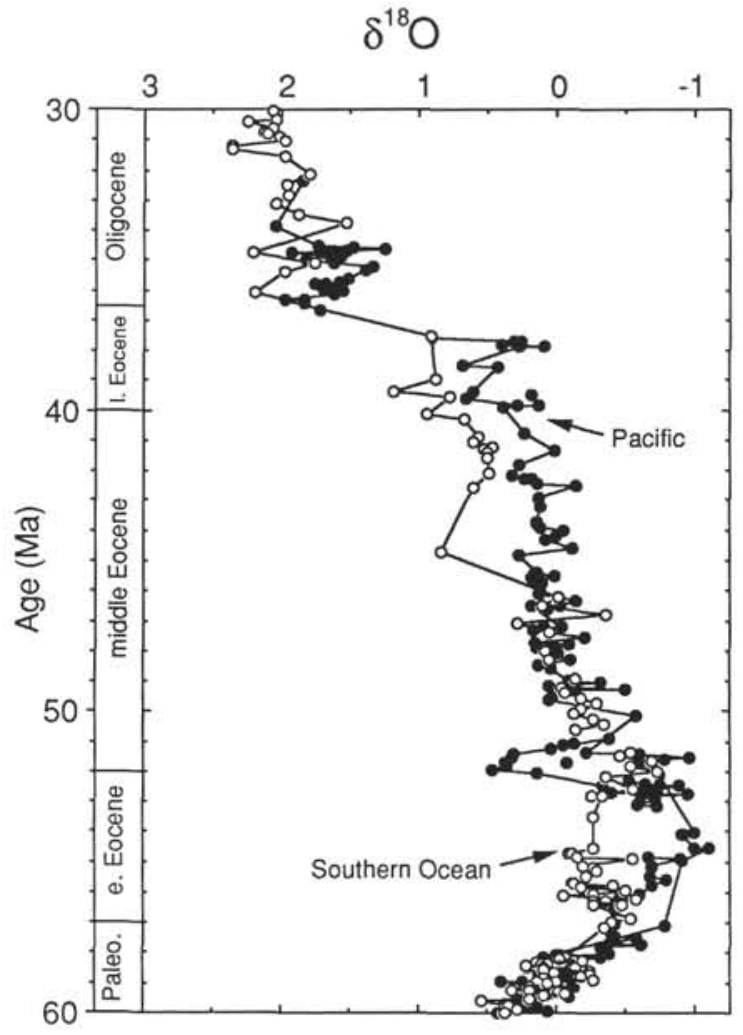

Figure 15. Comparison of the composite Pacific oxygen isotopic record (solid circles; includes data from Sites 883, 884, and 577) with the Southern Ocean record from Site 690 (open circles); data from Kennett and Stott (1990).

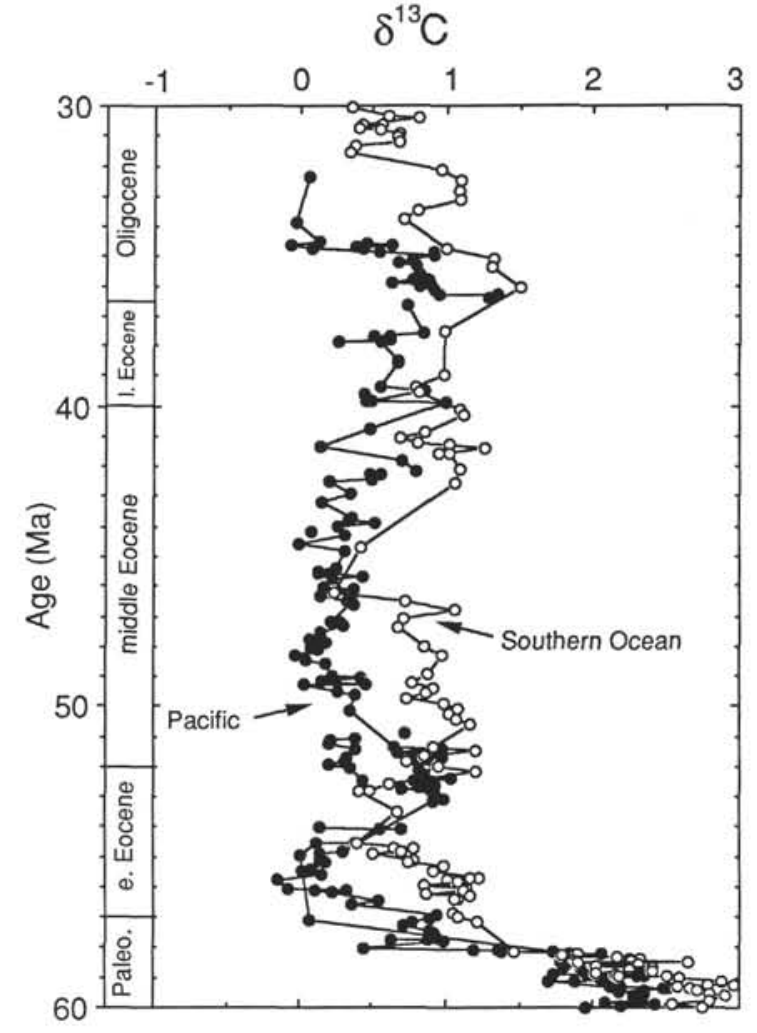

Figure 16. Comparison of the composite Pacific carbon isotopic record (solid circles; includes data from Sites 883, 884, and 577) with the Southern Ocean record from Site 690 (open circles); data from Kennett and Stott (1990).

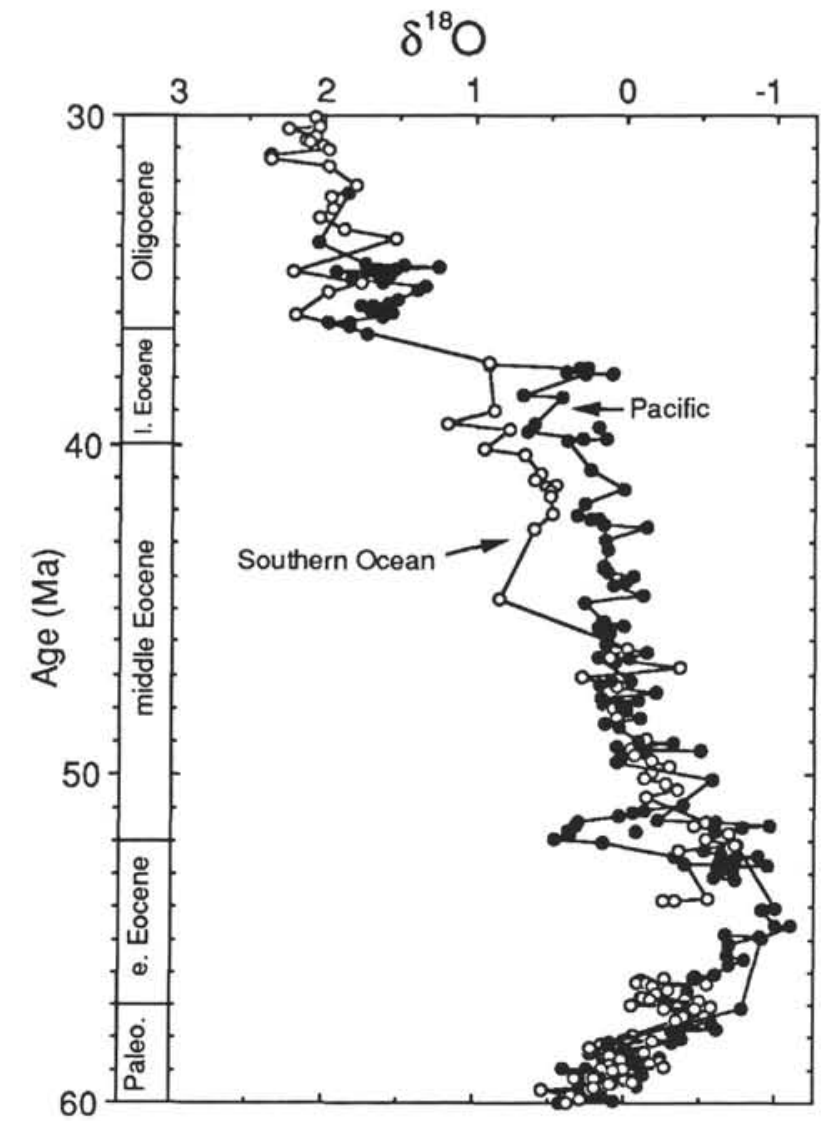

Figure 17. Comparison of the composite Pacific oxygen isotopic record (solid circles) with the Southern Ocean record (open circles) using the Aubry et al. (unpubl. data, 1994) stratigraphy. 


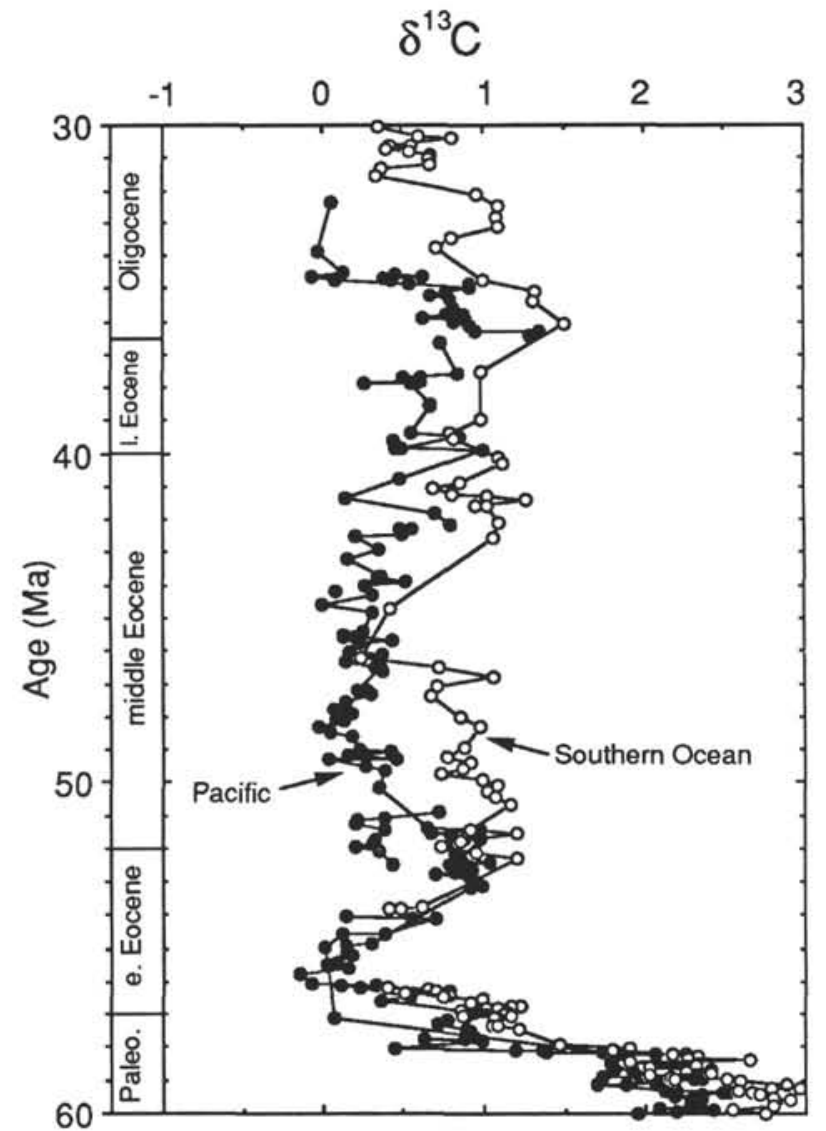

Figure 18. Comparison of the composite Pacific carbon isotopic record (solid circles) with the Southern Ocean record (open circles) using the Aubry et al. (unpubl. data, 1994) stratigraphy.

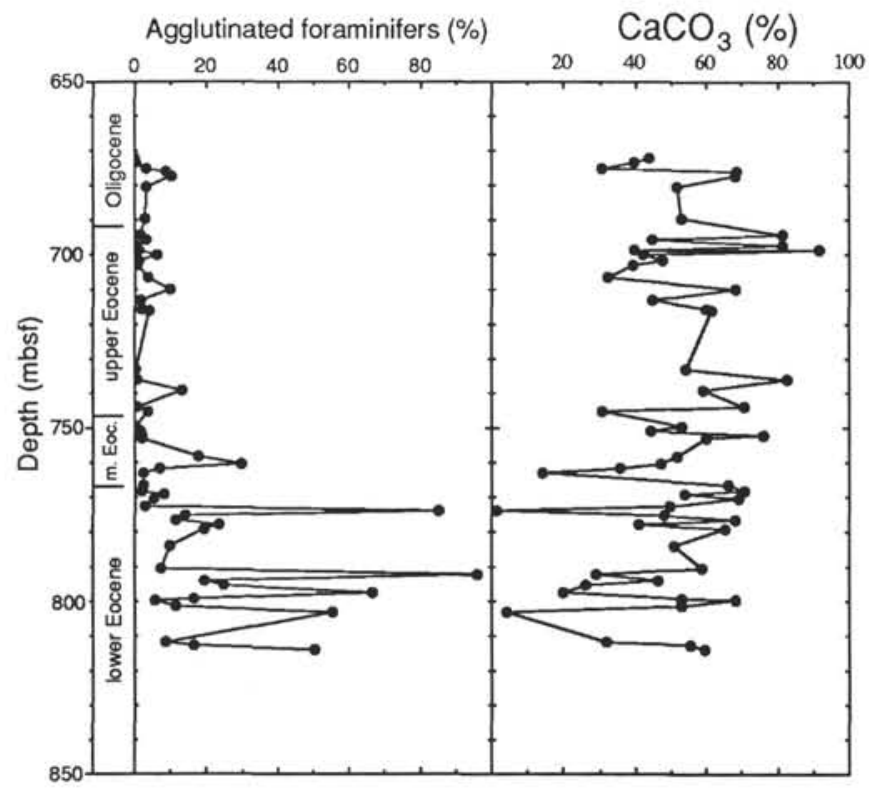

Figure 19. Comparison of the relative abundance of agglutinated taxa with percentage of carbonate at Site 884.

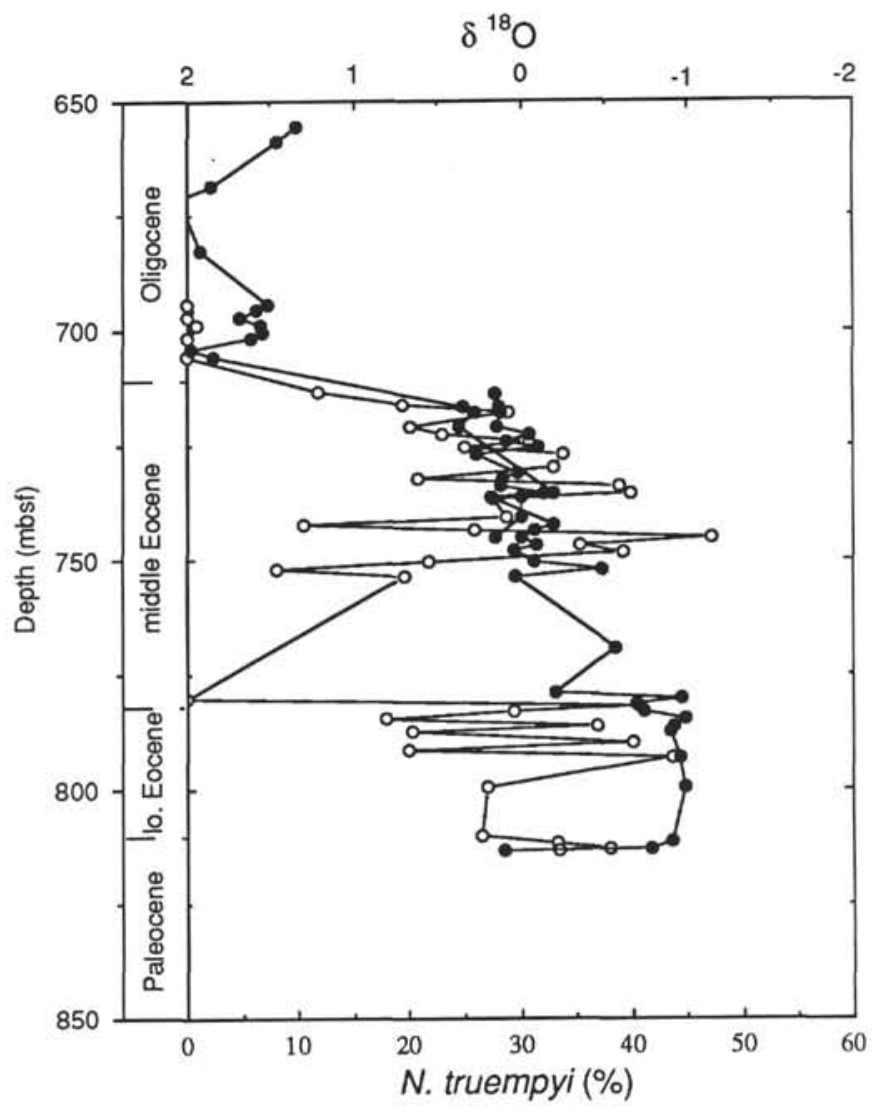

Figure 20. Comparison of the relative abundance of Nuttallides truempyi (open circles) with the oxygen isotopic record (solid circles) at Site 883. 